\title{
The neurons expressing calcium-binding proteins in the amygdala of the guinea pig: precisely designed interface for sex hormones
}

\author{
Maciej Równiak ${ }^{1}$
}

Received: 12 October 2016/Accepted: 24 April 2017/Published online: 29 April 2017

(C) The Author(s) 2017. This article is an open access publication

\begin{abstract}
The generation of emotional responses by the amygdala is determined largely by the balance of excitatory and inhibitory inputs to its principal neurons. These responses are often sex-specific, and any imbalance in excitatory and/or inhibitory tones leads to serious psychiatric disorders which occur with different rates in men versus women. To investigate the neural basis of sexspecific processing in the amygdala, relationships between the neurons expressing calbindin (CB), parvalbumin (PV) and calretinin $(\mathrm{CR})$, which form in the amygdala main subsets of $\gamma$-aminobutyric acid (GABA)-ergic inhibitory system, and neurons endowed with oestrogen alpha (ER $\alpha)$, oestrogen beta (ER $\beta)$ or androgen (AR) receptors were analysed using double immunohistochemistry in male and female guinea pig subjects. The results show that in various nuclei of the amygdala in both sexes small subsets of $\mathrm{CB}$ neurons and substantial proportions of PV neurons co-express ER $\beta$, while many of the CR neurons co-express ER $\alpha$. Both these oestrogen-sensitive populations are strictly separated as CB and PV neurons almost never co-express $\mathrm{ER} \alpha$, while CR cells are usually devoid of ER $\beta$. In addition, in the medial nucleus and some other neighbouring regions, there are non-overlapping subpopulations of $\mathrm{CB}$ and $\mathrm{CR}$ neurons which co-express AR. In conclusion, the localization of $\mathrm{ER} \alpha, \mathrm{ER} \beta$ or $\mathrm{AR}$ within subsets of GABAergic interneurons across diverse amygdaloid regions suggests that steroid hormones may exert a significant influence over local neuronal activity by directly
\end{abstract}

Maciej Równiak

mrowniak@uwm.edu.pl

1 Department of Comparative Anatomy, Faculty of Biology and Biotechnology, University of Warmia and Mazury in Olsztyn, pl. Łódzki 3, 10-727 Olsztyn, Poland modulating inhibitory tone. The control of inhibitory tone may be one of the mechanisms whereby oestrogen and androgen could modulate amygdala processing in a sexspecific manner. Another mechanism may be thorough steroid-sensitive projection neurons, which are most probably located in the medial and central nuclei.

Keywords Amygdala $\cdot$ Calcium-binding proteins $\cdot$ Steroid hormone receptors · Immunohistochemistry · Guinea pig

\section{Introduction}

The amygdala is composed of a set of nuclei and cortical regions within the temporal lobe which are thought to be critically important for emotional behaviour and emotional learning (LeDoux 2003; Sah et al. 2003; Pape and Pare 2010), mediation of pheromonal and reproductive functions (Baum 2009; Kevetter and Winans 1981; Martel and Baum 2009; Morris et al. 2008; Segovia et al. 2006), drug addiction mechanisms (Buffalari and See 2010) and stress response (LeDoux 1994). Although the general mechanisms of all these functions are similar in both sexes, there are also sexspecific details which make these functions sexually dimorphic (Hamann 2005; Fagergren and Hurd 1999; Gruene et al. 2015; Rollins and King 2000; Swaab et al. 2003). For example, women on average retain stronger and more vivid memories of emotional events than men (Seidlitz and Diener 1998; Canli et al. 2002). In addition, the fact that emotional memories tend to be stronger in women may be linked to the greater prevalence of depression and some types of anxiety disorders in women (Bekker and van Mens-Verhulst 2007; Davidson et al. 2002). Indeed, there are many other psychological disorders involving emotional function which occur with substantially different rates in men versus 
women. For example, anorexia is another disorder associated with amygdala dysfunction, which is observed more often in women than in men (Swaab et al. 2003). In contrast, schizophrenia, autism and drug addiction, also associated with abnormalities in the functioning of the amygdala, are quoted more frequently in men than in women (Swaab et al. 2003). It is worth mentioning that various aspects of amygdala anatomy are sexually dimorphic (Morris et al. 2008; Równiak 2013; Równiak et al. 2015; Segovia et al. 2006).

Circulating levels of sex hormones in the bloodstream constitute additional factors which may influence amygdala physiology and may drive amygdala responses in a sexspecific manner by acting through receptors expressed in specific amygdala nuclei. Indeed, the amygdala has a high density of oestrogen and androgen receptors, as well as high aromatase expression and activity (Shughrue et al. 1997; Lephart 1996). Moreover, these receptors and aromatase were found in both the glutamatergic principal neurons (Kiss et al. 2013) and $\gamma$-aminobutyric acid (GABA)ergic interneurons (Blurton-Jones and Tuszynski 2002), suggesting that excitation and inhibition in the amygdala may be substantially modulated by sex hormones. There is a growing body of evidence that oestrogens and androgens enhance glutamatergic neurotransmission and down-regulate GABAergic neurotransmission (Barth et al. 2015; Frye et al. 2008), although opposite effects have also been reported (Tan et al. 2012; Zhou et al. 2005). For example, Murphy et al. (1998) reported that oestradiol down-regulated brain-derived neurotrophic factor (BDNF) in cultured hippocampal cells and this effect was associated with an increase in excitatory tone leading to a twofold increase in dendritic spine density and a decrease in inhibition, as evidenced by decrease in glutamate decarboxylase (GAD) and GABA level. Moreover, as both glutamatergic and GABAergic cell types express GABA receptors, an oestradiol-induced decrease in GABAergic transmission to glutamatergic cells could effectively increase excitatory drive and thus favour the formation of new dendritic spines (Murphy et al. 1998; McDonald and Mascagni 2004). Further studies have confirmed that oestradiol enhances the magnitude of longterm potentiation in the hippocampus through facilitation of the $N$-methyl-D-aspartate receptors (NMDA) (Foy 2001; Córdoba Montoya and Carrer 1997; Smith et al. 2009). On the other hand, oestrogen has an ability to alter the frequency of GABAergic miniature inhibitory postsynaptic currents (Zhou et al. 2005). Moreover, other experiments have shown that ovariectomy and subsequent oestrogen replacement can alter mRNA levels of GABA receptor subunits, GABA transporter, and GAD, the rate-limiting enzyme in GABA synthesis (Nakamura et al. 2004; Herbison et al. 1995; Herbison and Fénelon 1995).
The generation of responses by the amygdala is determined largely by the balance of excitatory and inhibitory inputs to its principal projecting neurons. The activity of these neurons is tightly controlled by GABAergic interneurons, especially these expressing calbindin (CB), parvalbumin (PV) and calretinin (CR) (Sorvari et al. 1996; Muller et al. 2007; Woodruff and Sah 2007a). It is worth mentioning that each of these subpopulations, apart from GABA, also uses different neuropeptides. For example, CB-containing neurons often co-express somatostatin (SOM) and/or neuropeptide Y, whereas CR-positive cells often co-express cholecystokinin and/or vasoactive intestinal peptide (McDonald and Mascagni 2002; Mascagni and McDonald 2003). In contrast, PV neurons are devoid of any of these neuropeptides (Mascagni et al. 2009). Moreover, it should be kept in mind that some of the $\mathrm{CB}$ and $\mathrm{CR}$ neurons are not GABAergic interneurons but glutamatergic projecting neurons (Moryś et al. 1999; Kemppainen and Pitkänen 2000; McDonald et al. 2012). If the activity of various subpopulations of GABAergic neurons was strongly influenced by circulating steroid hormones via their receptors, inhibitory control in the amygdala could easily be driven in a sex-specific manner. Such modulation may have a huge impact on the amygdala's overall processing, and this way promotes sexually dimorphic responses. Although the amygdala has a large population of GABAergic neurons co-expressing $\mathrm{CB}, \mathrm{PV}$ or CR (Pitkänen and Amaral 1994) and a large population of cells bearing oestrogen alfa $(\mathrm{ER} \alpha)$, oestrogen beta $(\mathrm{ER} \beta)$ and androgen (AR) receptors (Shughrue et al. 1997; Warembourg and Leroy 2004; Wood and Newman 1999), little is known about relationships among all these populations. There are only two studies on the relationship between neurons expressing calcium-binding proteins and steroid receptors in the amygdala, and only one of them is quantitative (Blurton-Jones and Tuszynski 2002; Perez et al. 2004). However, in both of these studies the amygdala was just one of many brain centres studied. The quantitative study of Blurton-Jones and Tuszynski (2002) describes the co-expression pattern of PV interneurons with ER $\beta$-bearing cells in the selected nuclei of rat amygdala, where the counts were limited to the lateral and basomedial nuclei of female subjects. Perez et al. (2004) reported a lack of association between CB or PV-expressing neurons and $\mathrm{ER} \alpha$ in monkey forebrain, which was also studied in female subjects only. Thus, the present study investigates for the first time the co-localization pattern of $\mathrm{CB}, \mathrm{PV}$ or $\mathrm{CR}$ with $\mathrm{ER} \alpha, \mathrm{ER} \beta$ or $\mathrm{AR}$ in the amygdala of the guinea pig. Female and male subjects were taken into account to examine possible sex differences as well. To make the text easier to read, the neurons expressing CB, PV, CR, SOM, GABA, ER $\alpha, E R \beta$ and AR will be uniformly described as 
$\mathrm{CB}+, \mathrm{PV}+, \mathrm{CR}+, \mathrm{SOM}+, \mathrm{GABA}+, \mathrm{ER} \alpha+, \mathrm{ER} \beta+$ and $\mathrm{AR}+$ neurons.

\section{Materials and methods}

\section{Subjects}

Ten adult Dunkin-Hartley guinea pigs (Cavia porcellus, L.), five males and five females, at the age of 6 months and weighting $0.7-0.8 \mathrm{~kg}$ were used. All these animals were purchased from the professional supplier (Polish Mother's Health Centre in Łódź, Poland) to ensure their proper parameters such as the same strain, the same age, similar weight and proestrus phase in female subjects. The phase of the estrous cycle was determined directly from vaginal smears. Animal care and handling were in accordance with the European Union Directive for animal experiments (2010/63/EU) and were approved by the Local Ethical Commission of the University of Warmia and Mazury in Olsztyn (No. 27/2009). All efforts were made to minimize animal suffering and to use the minimum number of animals necessary to produce reliable scientific data.

\section{Tissue preparation}

All animals, i.e. males and females, were deeply anesthetized with an intraperitoneal injection of Morbital (Biowet, Poland; $2 \mathrm{ml} / \mathrm{kg}$ body weight, $133.3 \mathrm{mg} / \mathrm{ml}$ of pentobarbital sodium salt and $26.7 \mathrm{mg} / \mathrm{ml}$ of pentobarbital), and after cessation of breathing, immediately perfused transcardially with saline $(0.9 \%)$ followed by $4 \%$ paraformaldehyde ( $\mathrm{pH}$ 7.4) in phosphate-buffered saline (PBS). Following perfusion, brains were dissected out from the skulls, postfixed overnight in the same fixative, washed twice in $0.1 \mathrm{M}$ phosphate buffer $\left(\mathrm{pH}=7.4,4{ }^{\circ} \mathrm{C}\right)$ and then stored for 3-5 days in graded solutions (19\% and 30\%) of sucrose (Sigma Aldrich) at $4{ }^{\circ} \mathrm{C}$ until they sank. Finally, the brains were frozen and then coronally sectioned at a thickness of $10 \mu \mathrm{m}$ using a cryostat. The sections were mounted on object slides and stored at $-80{ }^{\circ} \mathrm{C}$ until further processing.

\section{Immunofluorescence experiments}

Amygdala sections were processed for routine doubleimmunofluorescence labelling using primary antisera raised in different species and species-specific secondary antibodies (Table 1). As each slide contained two sections, five neighbouring slides (ten neighbouring sections) were always used for staining with the use of seven different primary antibodies. Nine of these ten sections were used for the main experiment (co-localization of 3 calcium-binding proteins and 3 steroid receptors) and one spare section was used for pan-neuronal marker to visualize amygdaloid nuclei. In addition, some sections in three male and three female subjects were destined for additional staining described in the present study.

All samples were washed three times in PBS and then incubated for $1 \mathrm{~h}$ in humid chambers with blocking buffer (0.1 M PBS, 10\% normal donkey serum, $0.01 \%$ bovine serum albumin, $1 \%$ Tween, $0.05 \%$ thimerosal, $0.01 \%$ $\mathrm{NaN}_{3}$ ). The sections were then rinsed in PBS and incubated overnight at room temperature with a mixture of primary antibodies, namely a combination of the appropriate primary antibody to one of the calcium-binding proteins $(\mathrm{CB}$ or $\mathrm{PV}$ or $\mathrm{CR})$ and one to the steroid receptor (ER $\alpha$ or $\mathrm{ER} \beta$ or AR) (Table 1). Additional incubations included neuronspecific nuclear protein NeuN (pan-neuronal marker) or mixtures consisting of $\mathrm{CB}$ and $\mathrm{PV}, \mathrm{CB}$ and $\mathrm{CR}$ or SOM with one of the steroid receptors (Table 1). The antibodies were diluted in PBS containing Triton X-100 (0.3-0.5\%) and $1 \%$ normal donkey serum. After incubation with the primary antibodies, the sections were rinsed in PBS and incubated for $1 \mathrm{~h}$ with a mixture of species-specific secondary antibodies (Table 1). Finally, all samples were rinsed in PBS and then mounted with carbonate-buffered glycerol $(\mathrm{pH} 8.6)$ and coverslipped.

\section{Controls}

The specificity of the primary antisera used in this study has been shown by various researchers using these products in multiple previous studies (Airaksinen et al. 1997; Drexel et al. 2011; Meszar et al. 2012; Zimmermann and Schwaller 2002; Stanić et al. 2014; Kritzer 2004; Wood and Newman 1999). In addition, product descriptions of rabbit anti-calbindin (CB-38), mouse anti-calbindin (300), and mouse anti-calretinin $\left(6 \mathrm{~B}_{3}\right)$ antisera include immunoblots of the guinea pig brain homogenates, which were specifically stained by these antibodies, showing bands at 28, 28 and $29 \mathrm{kDa}$, respectively. The same documents show also absence of specific immunohistochemical staining in brains sections of CB or CR knock-out mice using these antibodies. The rabbit antisera towards ER $\alpha$ (06-535), ER $\beta$ (05-824) and AR (06-680) were tested by immunoblots and these antibodies specifically stained the mouse brain extracts showing single bands at 66, 59 and $110 \mathrm{kDa}$, respectively (Stanić et al. 2014). The specificity of secondary antibodies was controlled by the omission and replacement of all primary antisera by non-immune sera or PBS. Lack of any immunoreactions indicated specificity. 
Table 1 Specification of reagents

\begin{tabular}{lllllll}
\hline Antigen & Code & Clonality & Host species & Dilution & Supplier & Location \\
\hline $\begin{array}{l}\text { Primary antibodies } \\
\text { NEUN }\end{array}$ & MAB377 & monoclonal & Mouse & $1: 2000$ & Millipore & Temecula, CA/USA \\
CB & 300 & monoclonal & Mouse & $1: 2000$ & SWANT & Bellinzona/Switzerland \\
CB & CB-38 & polyclonal & Rabbit & $1: 4000$ & SWANT & Bellinzona/Switzerland \\
PV & P3088 & monoclonal & Mouse & $1: 4000$ & Sigma Aldrich & St. Louis, MO/USA \\
CR & $6 B_{3}$ & monoclonal & Mouse & $1: 4000$ & SWANT & Bellinzona/Switzerland \\
ER $\alpha$ & $06-935$ & polyclonal & Rabbit & $1: 400$ & Millipore & Temecula, CA/USA \\
ER $\beta$ & $05-824$ & monoclonal & Rabbit & $1: 400$ & Millipore & Temecula, CA/USA \\
AR & $06-680$ & polyclonal & Rabbit & $1: 500$ & Millipore & Temecula, CA/USA \\
SOM & MAB354 & monoclonal & Rat & $1: 200$ & Millipore & Temecula, CA/USA \\
Secondary antibodies & & & & & ThermoFisher & Rockford, IL/USA \\
ALEXA Fluor 488 & A-21202 & polyclonal & Mouse & $1: 800$ & ThermoFisher & Rockford, IL/USA \\
ALEXA Fluor 555 & A-31572 & polyclonal & Rabbit & $1: 800$ & West Grove, PA/USA \\
FITC & $712-095-153$ & polyclonal & Rat & $1: 600$ & Jackson ImmunoLabs & West \\
\hline
\end{tabular}

\section{Counts and statistics}

Colocalizations of $\mathrm{CB}+, \mathrm{PV}+$ and $\mathrm{CR}+$ cells with particular steroid receptors were analysed in the lateral, basolateral, basomedial, central, medial and cortical amygdaloid nuclei using an Olympus BX51 microscope equipped with Cell-F image analysis software (Olympus $\mathrm{GmbH}$, Germany). Only the numbers of single- and double-labelled $\mathrm{CB}+, \mathrm{PV}+$ and $\mathrm{CR}+$ cells were counted. Single-labelled ER $\alpha+, \mathrm{ER} \beta+$ or AR + cells were excluded from the investigation. For each nucleus in each animal of both sexes, particular combinations of antigens were counted on 10 evenly spaced sections arranged from the rostral to the caudal extent. The space between sections analysed per specific nucleus depended on the nucleus length, and these values were as follows: LA: $250 \mu \mathrm{m}, \mathrm{BL}$ : $200 \mu \mathrm{m}, \mathrm{BM}: 200 \mu \mathrm{m}, \mathrm{CE}: 200 \mu \mathrm{m}$, ME: $200 \mu \mathrm{m}$ and CO: $250 \mu \mathrm{m}$. In order to confirm the localization of the individual nuclei on the sections, neighbouring sections stained with mouse anti-NeuN (pan-neuronal marker) were used. All counts on the single section were made at $20 \times$ magnification using $347.6 \mu \mathrm{m} \times 260.7 \mu \mathrm{m}$ regions. The test frames were arranged in a way that ensured coverage of the whole cross-sectional area of each nucleus studied. The numbers of test frames studied per nucleus were as follows: LA: 5-7, BL: 2-4, BM: 2-3, CE: 2-4, ME: 3-4 and CO: $2-3$. Within test frames single-labelled and double-labelled neurons were counted separately. Such separate counts made within the test frames in the single nucleus in the subject were totalled. Finally, counts from each nucleus were averaged in each sex group and expressed as mean \pm standard deviation (SD). All counts were made on coded slides by the author. To avoid fluorescence fading, test frame was digitally recorded before counting. Such digital frames were in the form of stacks which were composed of two microphotographs representing red and green immunofluorescence channels. Saved stacks were also evaluated by two independent experimenters, being blind to the parameters of the studied tissues (sex, nucleus, antigens, etc.). The results of these counts showed high inter-rater reliability (Pearson $R=0.86, p<0.001$ ). Statistical differences between the two experimental groups (males vs. females) were analysed with a two-tailed $t$ test $\left({ }^{*} p \leq 0.05, * * p \leq 0.01\right.$ and $\left.{ }^{* *} p \leq 0.001\right)$ using GraphPad Prism 5 software (GraphPad Software, La Jolla, CA, USA).

As the population of $\mathrm{CB}+$ neurons in the amygdala consists of two separate and non-overlapping subpopulations such as $\mathrm{CB}+/ \mathrm{PV}+$ and $\mathrm{CB}+/ \mathrm{SOM}+$ cells, additional staining was performed to clarify the relationships between $\mathrm{CB}+$ neurons and either $\mathrm{PV}+$ or $\mathrm{CR}+$ cells, as well as between $\mathrm{SOM}+$ neurons and either ER $\beta+$ or $\mathrm{AR}+$ cells. All these sections were analysed using an epifluorescence microscope. However, the SOM signal was present only in cytoplasm, while the AR signal was present only in cell nuclei, and thus in many double-stained cells the colocalization was not obvious. Therefore, to unequivocally ascertain that SOM and AR co-exist in the same neurons, additional analysis was performed with the use of a confocal microscope. All additional sections were also evaluated quantitatively in a way described above ( 5 sections per nucleus in 3 male and 3 female subjects). In the case of $C B$ staining, only single and double-labelled $\mathrm{CB}+$ neurons were counted, whereas single-labelled $\mathrm{PV}+$ or $\mathrm{CR}+$ cells 
were excluded from analysis. In the case of SOM preparations, only single- and double-labelled SOM+ neurons were counted, while single-labelled $\mathrm{ER} \beta+$ or $\mathrm{AR}+$ cells were excluded from investigation.

\section{Photomicrographic production}

Low- and high-magnification photomicrographs of immunoreactive cells were taken with a CC-12 digital camera (Soft Imaging System GMBH, Germany) on an Olympus BX51 microscope. These digital images were slightly modified to optimise the image resolution, brightness and contrast using CS4, version 11.0, software (Adobe Systems Inc., San Jose, CA, USA). Low- and high-magnification confocal fluorescent images (Fig. 4d-f) were obtained with a Leica TCS SP5 microscope (Wetzlar, Germany). Sequential excitation at $488 \mathrm{~nm}$ and $561 \mathrm{~nm}$ was provided by argon and DPSS 561 lasers, respectively. Schematic drawings demonstrating the distribution patterns of $\mathrm{ER} \alpha+, \mathrm{ER} \beta+$ and $\mathrm{AR}+$ cells were created by marking with a dot each neuron on the digitalized section and superimposing outlines from the adjacent anti-NeuN sections.

\section{Results}

\section{Distribution of $\mathrm{CB}+, \mathrm{PV}+, \mathrm{CR}+$ and $\mathrm{SOM}+$ neurons in the amygdala of male and female guinea pig}

The position of the various nuclei in the guinea pig amygdala as well as the distributions of $\mathrm{CB}+, \mathrm{PV}+$ and $\mathrm{CR}+$ neurons in this region were precisely described in both sexes in our previous reports concerned with sex differences existing in this species (Równiak 2013; Równiak et al. 2015). The distribution pattern of SOM+ neurons in the guinea pig amygdala was very similar to that described in the rat (McDonald 1989) and pig (Równiak et al. 2008). In the present study, the same six main amygdaloid regions, i.e. the lateral, basolateral, basomedial, central, medial and cortical nuclei were chosen for detailed investigation. In all these regions, the relationships between $\mathrm{CB}+, \mathrm{PV}+$ or $\mathrm{CR}+$ neurons and $\mathrm{ER} \alpha+, \mathrm{ER} \beta+$ or $\mathrm{AR}+$ cells were analysed and compared between the sexes.

\section{Distribution of ER $\alpha+, E R \beta+$ and $A R+$ neurons in the amygdala of male and female guinea pig}

An analysis of the distributions of $\mathrm{ER} \alpha+, \mathrm{ER} \beta+$ and $\mathrm{AR}+$ immunoreactivities in the amygdala of male and female guinea pig revealed large numbers of weakly to strongly stained cells throughout the entire rostral to caudal continuum of the amygdala (Figs. 1, 2). In both sexes, $\mathrm{ER} \alpha+$ cells were the most numerous, while ER $\beta+$ neurons were the least numerous. The subcellular distribution of these immunoreactivities was predominantly nuclear in most neurons (Fig. 2). However, in some cells, the cytoplasm and neuronal processes were also immunostained.

Although, populations of $\mathrm{ER} \alpha+, \mathrm{ER} \beta+$ and $\mathrm{AR}+$ neurons had slightly different patterns of distribution in the amygdala, these three patterns also had many common features (Figs. 1, 2). For example, in both sexes, the ER $\alpha+$, $\mathrm{ER} \beta+$ and $\mathrm{AR}+$ cells were the most numerous and the most densely packed in the medial nucleus (Figs. 1, 2). Moreover, in the posterodorsal portion of the medial nucleus, the ER $\alpha+, \mathrm{ER} \beta+$ and AR+ cells were among the most intensely labelled, whereas in the other nuclei of the amygdala the intensity was weaker. Another characteristic and common feature was clusters of intensely stained $\mathrm{ER} \alpha+, \mathrm{ER} \beta+$ and $\mathrm{AR}+$ cells in the intra-amygdaloid division of the bed nucleus of the stria terminalis and scattered neurons in the central nucleus. In the basolateral complex of the amygdala, only the basomedial nucleus contained many $\mathrm{ER} \alpha+, \mathrm{ER} \beta+$ and $\mathrm{AR}+$ cells. On the other hand, in the lateral and basolateral nuclei fewer $\mathrm{ER} \alpha+, \mathrm{ER} \beta+$ and $\mathrm{AR}+$ signals were found (Figs. 1, 2). However, in the lateral nucleus, the density of $\mathrm{ER} \alpha+$ nuclei was quite moderate. In the amygdalohippocampal area, $\mathrm{ER} \alpha+$ and $\mathrm{AR}+$ cells were abundant, but relatively few ER $\beta+$ cells were found (Figs. 1, 2). In contrast, ER $\alpha+$ cells were much more numerous than $\mathrm{ER} \beta+$ or $\mathrm{AR}+$ neurons in cortical nuclei (Figs. 1, 2).

\section{Co-existence pattern of $\mathrm{CB}+, \mathrm{PV}+$ and $\mathrm{CR}+$ neurons with $E R \alpha, E R \beta$ or $A R$ in the amygdala of male and female guinea pig}

All details concerning the co-existence of $\mathrm{CB}+, \mathrm{PV}+$ and $\mathrm{CR}+$ neurons with $\mathrm{ER} \alpha+, \mathrm{ER} \beta+$ and $\mathrm{AR}+$ in the amygdala of male and female guinea pig are shown in Tables 2, 3, 4 and 5 and Figs. 3, 4, 5 and 6. These details clearly demonstrate that: $\mathrm{CB}+, \mathrm{PV}+$ and $\mathrm{CR}+$ neurons have different and unique patterns of co-expression with $\mathrm{ER} \beta, \mathrm{ER} \alpha$ and AR; there is cellular separation of ER $\beta, E R \alpha$ and $A R$ within non-overlapping subpopulations of $\mathrm{CB}+\mathrm{PV}+$ and $\mathrm{AR}+$ cells; the patterns and extents of co-expression are very similar in both sexes.

\section{Calbindin neurons}

Small proportions of $\mathrm{CB}+$ neurons in the amygdala were costained for ER $\beta$ or AR, but these cells almost never coexpressed ER $\alpha$ (Table 2; Fig. 3). Double-labelled neurons for $C B$ and $E R \beta$ were observed in all the nuclei studied, although the percentages differed substantially among 


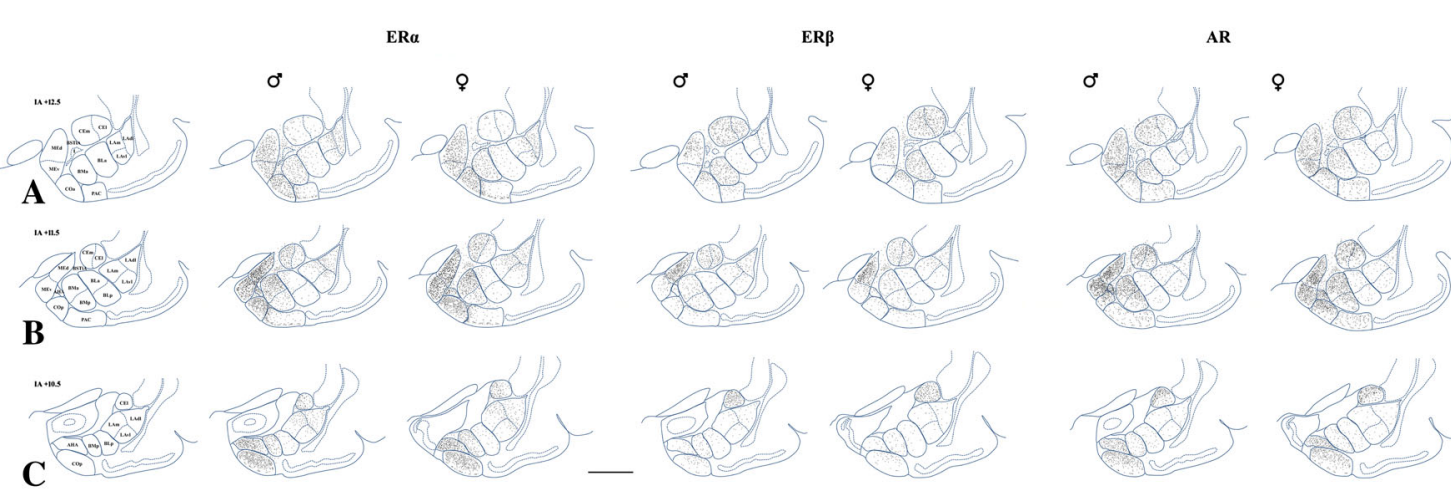

Fig. 1 Computer-generated plots illustrating an overview of the distribution of $\mathrm{ER} \alpha+, \mathrm{ER} \beta+$ and $\mathrm{AR}+$ neurons in the whole amygdala at various coronal levels in the male and female subjects. Note the differences in the density of ER $\alpha+, E R \beta+$ and AR+ cells at various coronal levels. Note also differences in the density of $\mathrm{ER} \alpha+$, $\mathrm{ER} \beta+$ and AR+ cells between "cortex-like" and "striatum-pallidumlike nuclei". Each dot represents one immunostained nucleus. Three coronal levels are presented (A is the most rostral, $\mathbf{B}$ ismiddle, and $\mathbf{C}$ is the most caudal). The numbers shown in the upper left corners represent distances in millimetres from the interaural plane (IA) which was used as a rostrocaudal zero reference point for the coronal sections in the guinea pig forebrain atlas of Tindal (1965). These stereotaxic coordinates are used only as a guide, and are given to allow the reader to refer to the atlas. Scale bar $2000 \mu \mathrm{m}$ in $\mathbf{C}$ (applies to all sections). $A H A$ amygdalohippocampal area, $B L a$ basolateral nucleus, anterior part, $B L p$ basolateral nucleus, posterior part, $B M a$ basomedial nucleus, anterior part, $B M p$ basomedial nucleus, posterior part, BSTiA bed nucleus of the stria terminalis, intraamygdaloid part, $C E l$ central nucleus, lateral part, $C E m$ central nucleus, medial part, $\mathrm{COa}$ anterior cortical nucleus, $\mathrm{COp}$ posterior cortical nucleus, $I$ intercalated nucleus, $L A d l$ lateral nucleus, dorsolateral part, $L A v l$ lateral nucleus, ventrolateral part, $L A m$ lateral nucleus, medial part, $M E d$ medial nucleus, dorsal part, $M E v$ medial nucleus, ventral part, $P A C$ periamygdalod cortex
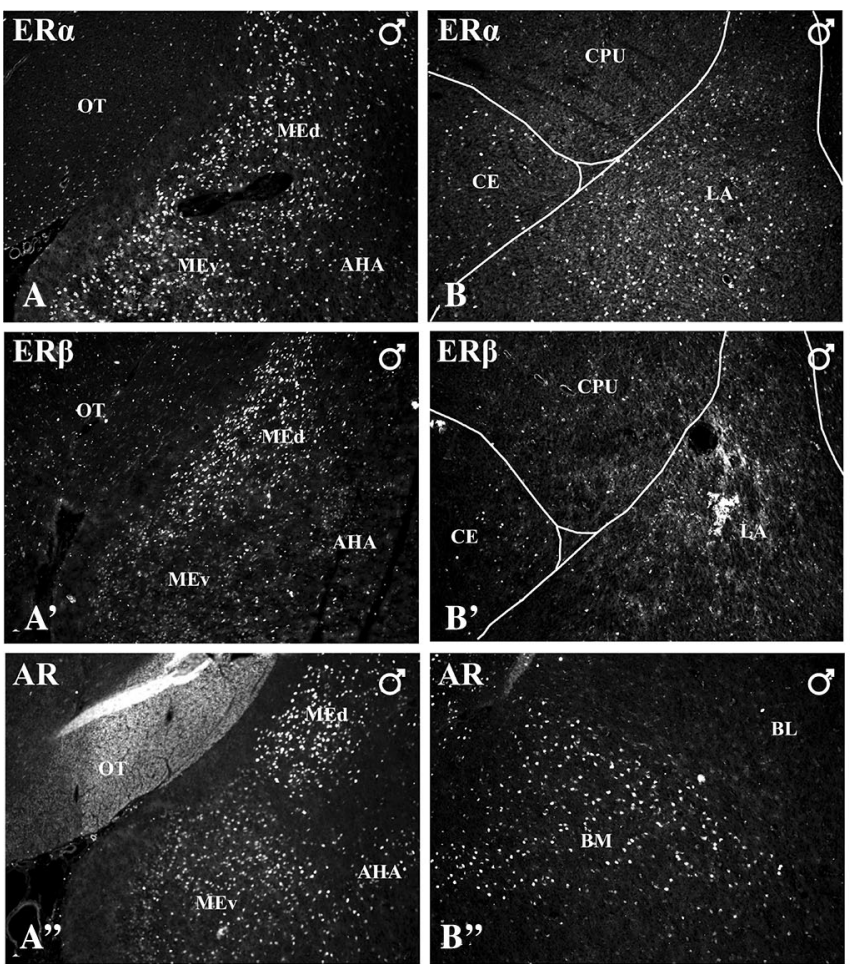

Fig. 2 Distribution of neurons expressing ER $\alpha$ (A-D), ER $\beta$ (A'-D') or AR (A"-D") within the amygdala of male (A-B, A'-B', $\mathbf{A}$ "-B") and female (C-D, C'-D', C'-D") guinea pigs. A-D: low-magnification view of the ER $\alpha$ immunofluorescence showing large numbers of $\mathrm{ER} \alpha+$ neurons in the medial and lateral nuclei. A'-D': lowmagnification view of the ER $\beta+$ immunoreactivity showing large numbers of ER $\beta+$ cells in the medial but not lateral nucleus. A"-D": low-magnification view of the AR+ immunofluorescence demonstrating densely arranged AR + cells in the medial and basomedial
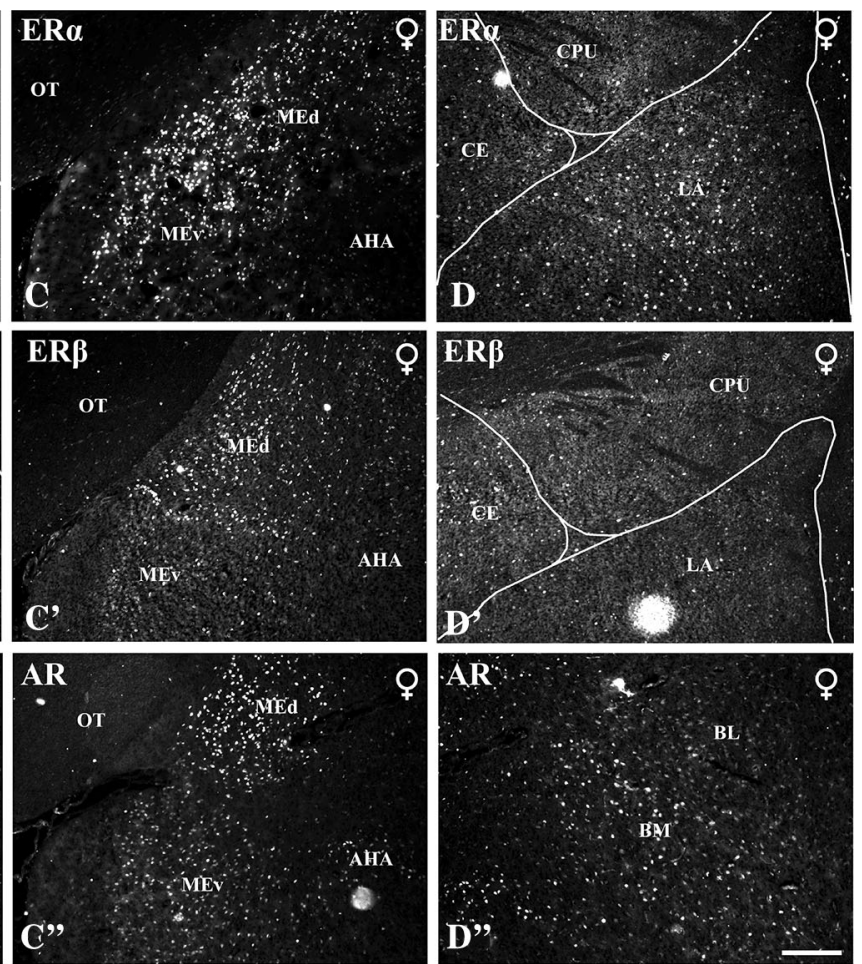

nuclei. Note that within the medial nucleus ER $\alpha+$ neurons are densely arranged in both parts, ER $\beta+$ cells are more numerous in dorsal part and AR+ neurons are more intensely stained in the dorsal part. Scale bar $200 \mu \mathrm{m}$ in D" (applies to all sections). AHA amygdalohippocampal area, $B L$ basolateral nucleus, $B M$ basomedial nucleus, $C E$ central nucleus, $C P U$ caudatoputamen, $L A$ lateral nucleus, $M E$ medial nucleus, $M E d$ dorsal part, $M E v$ ventral part, $O T$ optic tract 


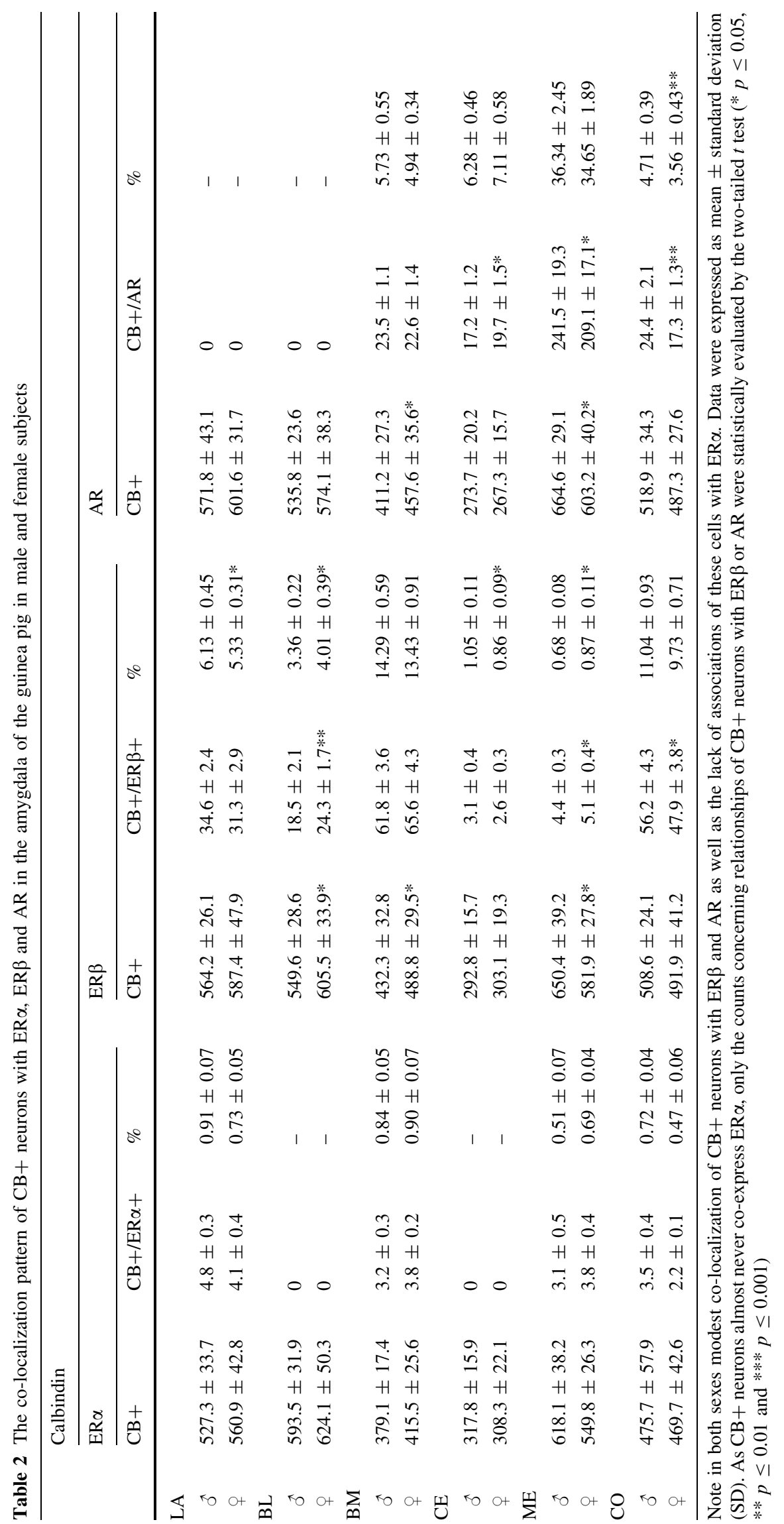




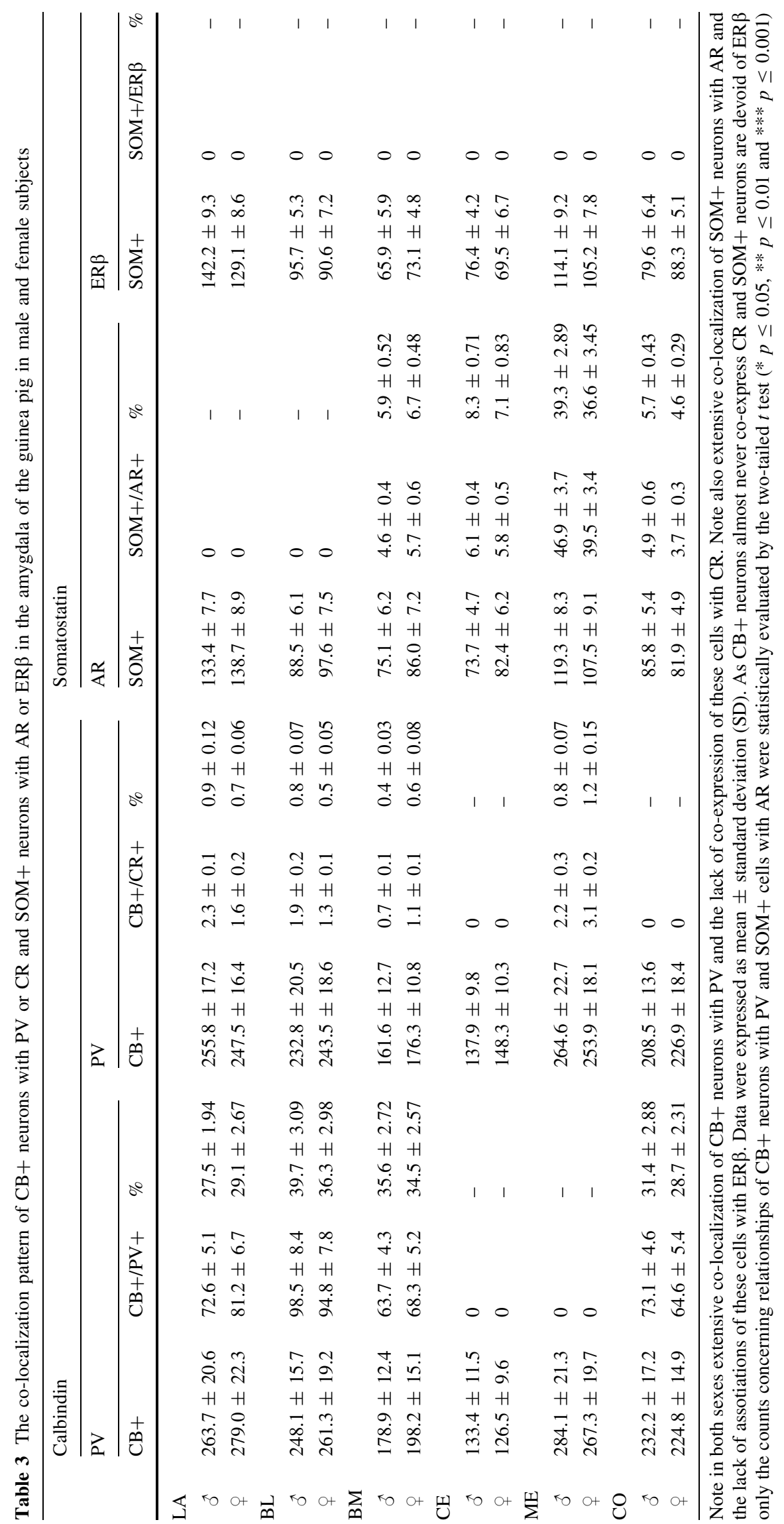


Table 4 The co-localization pattern of PV+ neurons with ER $\alpha, E R \beta$ and AR in the amygdala of the guinea pig in male and female subjects Parvalbumin

\begin{tabular}{|c|c|c|c|c|c|c|c|c|c|}
\hline & \multicolumn{3}{|l|}{$\mathrm{ER} \alpha$} & \multicolumn{3}{|l|}{ ER $\beta$} & \multicolumn{3}{|l|}{$\mathrm{AR}$} \\
\hline & $\mathrm{PV}+$ & $\mathrm{PV}+/ \mathrm{ER} \alpha+$ & $\%$ & $\mathrm{PV}+$ & $\mathrm{PV}+/ \mathrm{ER} \beta+$ & $\%$ & $\mathrm{PV}+$ & $\mathrm{PV}+/ \mathrm{AR}$ & $\%$ \\
\hline \multicolumn{10}{|l|}{ LA } \\
\hline$\hat{\sigma}$ & $619.3 \pm 51.2$ & $4.1 \pm 0.4$ & $0.66 \pm 0.05$ & $662.4 \pm 32.3$ & $92.3 \pm 6.9$ & $13.93 \pm 0.81$ & $628.3 \pm 39.6$ & 0 & - \\
\hline 우 & $675.6 \pm 39.1$ & $3.3 \pm 0.3$ & $0.49 \pm 0.07$ & $746.5 \pm 47.9 *$ & $127.8 \pm 9.8^{* *}$ & $17.12 \pm 1.42 * *$ & $694.8 \pm 53.5$ & 0 & - \\
\hline \multicolumn{10}{|l|}{ BL } \\
\hline$\hat{\sigma}$ & $446.2 \pm 27.9$ & 0 & - & $467.2 \pm 42.7$ & $32.1 \pm 2.2$ & $6.87 \pm 0.54$ & $484.2 \pm 35.8$ & 0 & - \\
\hline 우 & $499.3 \pm 40.8$ & 0 & - & $522.8 \pm 29.9$ & $29.5 \pm 2.6$ & $5.65 \pm 0.47^{*}$ & $537.1 \pm 33.1$ & 0 & - \\
\hline \multicolumn{10}{|l|}{ BM } \\
\hline$\hat{o}$ & $278.9 \pm 19.7$ & $2.6 \pm 0.3$ & $0.92 \pm 0.17$ & $304.8 \pm 23.1$ & $88.7 \pm 6.3$ & $29.15 \pm 2.52$ & $316.8 \pm 24.0$ & $2.6 \pm 0.3$ & $0.81 \pm 0.09$ \\
\hline q & $301.3 \pm 18.6$ & $3.1 \pm 0.4$ & $1.02 \pm 0.23$ & $346.6 \pm 15.7 *$ & $109.3 \pm 7.5^{* *}$ & $31.54 \pm 1.87$ & $332.4 \pm 19.1$ & $1.2 \pm 0.1$ & $0.34 \pm 0.05$ \\
\hline \multicolumn{10}{|l|}{$\mathrm{CE}$} \\
\hline$\hat{\sigma}$ & $9.3 \pm 0.3$ & 0 & - & $9.6 \pm 0.8$ & 0 & - & $11.2 \pm 1.4$ & 0 & - \\
\hline 우 & $7.1 \pm 0.5$ & 0 & - & $8.7 \pm 0.7$ & 0 & - & $6.1 \pm 0.6$ & 0 & - \\
\hline \multicolumn{10}{|l|}{ ME } \\
\hline$\hat{o}$ & $15.2 \pm 0.8$ & 0 & - & $16.8 \pm 1.3$ & 0 & - & $13.3 \pm 0.8$ & 0 & - \\
\hline 우 & $13.5 \pm 0.9$ & 0 & - & $15.5 \pm 1.1$ & 0 & - & $10.6 \pm 0.5$ & 0 & - \\
\hline \multicolumn{10}{|l|}{$\mathrm{CO}$} \\
\hline$\hat{\sigma}$ & $237.4 \pm 10.2$ & $2.4 \pm 0.2$ & $1.03 \pm 0.15$ & $250.4 \pm 19.8$ & $65.4 \pm 3.4$ & $26.12 \pm 1.27$ & $268.1 \pm 14.3$ & $2.9 \pm 0.2$ & $1.07 \pm 0.08$ \\
\hline q & $225.2 \pm 11.6$ & $1.2 \pm 0.1$ & $0.53 \pm 0.06$ & $219.6 \pm 15.9^{*}$ & $56.2 \pm 3.8^{*}$ & $25.61 \pm 1.43$ & $241.9 \pm 17.6$ & $1.8 \pm 0.1$ & $0.76 \pm 0.04$ \\
\hline
\end{tabular}

Note in both sexes extensive co-localization of PV+ neurons with ER $\beta$ and the lack of associations of these cells with ER $\alpha$ or AR. Data were expressed as mean \pm standard deviation (SD). As PV+ neurons almost never co-express ER $\alpha$ or AR, only the counts concerning relationships of $\mathrm{PV}+$ neurons with ER $\beta$ were statistically evaluated by the two-tailed $t$ test $\left(* p \leq 0.05,{ }^{*} p \leq 0.01\right.$ and $\left.* * * p \leq 0.001\right)$

various regions. For example, within the lateral and basolateral nuclei, less than $7 \%$ of $\mathrm{CB}+$ neurons co-expressed $\mathrm{ER} \beta$, but within the basomedial nucleus, the percentage of such neurons was two times higher. Within the central and medial nuclei, double-labelled cells were observed only occasionally, while within the cortical nuclei approximately $10 \%$ of $\mathrm{CB}+$ cells were costained for ER $\beta$. Doublelabelled neurons for $\mathrm{CB}$ and $\mathrm{AR}$ were observed within the central, medial, basomedial and cortical nuclei (Table 2; Fig. 3). With the exception of the medial nucleus, where almost $37 \%$ of $\mathrm{CB}+$ neurons were $\mathrm{AR}+$, in the other regions such double-labelled cells were much less numerous.

As population of $\mathrm{CB}+$ neurons in the amygdala consists of two separate and non-overlapping subpopulations such as $\mathrm{CB}+/ \mathrm{PV}+$ and $\mathrm{CB}+/ \mathrm{SOM}+$ cells, additional staining was performed to verify which $\mathrm{CB}+$ neurons may co-express ER $\beta$ or AR (Fig. 4). Double-immunofluorescence with antibodies against $\mathrm{CB}$ and PV revealed the substantial overlap of both markers, suggesting that at least a part of $\mathrm{CB}+/ \mathrm{ER} \beta+$ neurons may contain PV as well (Fig. 4a). For example, in the lateral and basolateral nuclei, approximately 30 and $40 \%$ of $\mathrm{CB}+$ neurons co-expressed PV in male and female subjects, respectively (Table 3). Doubleimmunofluorescence with antibodies against SOM and ER $\beta$ demonstrated the lack of any co-existence of both these markers in the same neurons (Table 3; Fig. 4c). In contrast, SOM and AR co-existed in the same cells in the medial nucleus and neighbouring regions (Fig. $4 \mathrm{~d}-\mathrm{f}$ ). In the medial nucleus approximately $40 \%$ of SOM + neurons were simultaneously AR+ (Table 3 ). In the basomedial, cortical and central nuclei, only single cells were doublelabelled for SOM and AR (Table 3).

\section{Parvalbumin neurons}

A substantial proportion of $\mathrm{PV}+$ neurons in the amygdala co-expressed ER $\beta$, but these cells almost never co-expressed ER $\alpha$ or AR (Table 4; Fig. 5). Within the lateral and basolateral nuclei, approximately 15 and $7 \%$ of PV+ neurons co-expressed ER $\beta$, respectively, whereas within the basomedial nucleus one-third of these cells were simultaneously ER $\beta+$. Within the medial and central nuclei, there were no neurons double-labelled for PV and ER $\beta$ due to the limited number of PV+ cells in both these regions. Within the cortical nuclei, double-labelled cells 


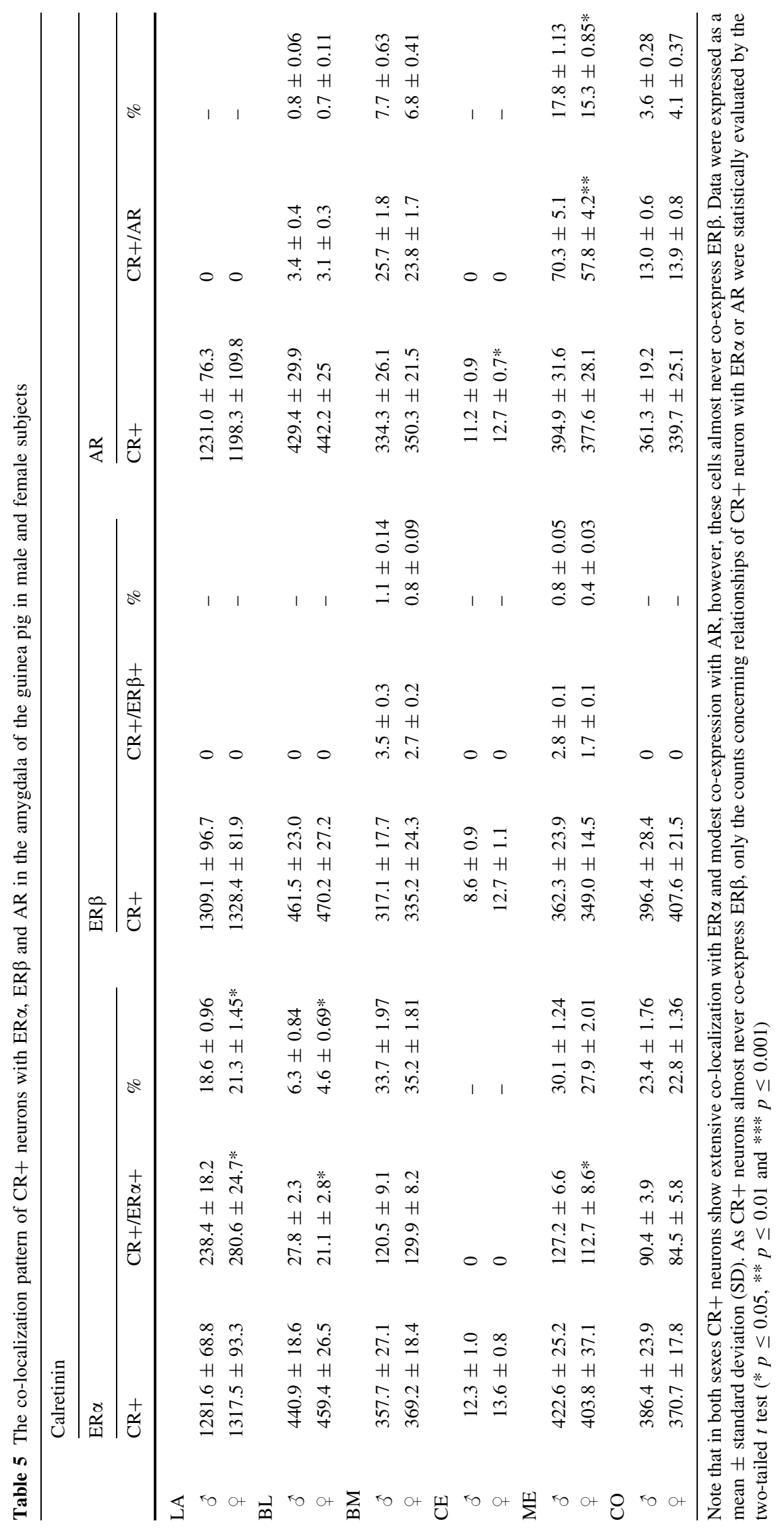


Fig. 3 Representative colour photomicrographs illustrating the anatomical relationships between $\mathrm{CB}+$ neurons and nuclei immunoreactive for $\mathrm{ER} \alpha$ $(\mathbf{A}, \mathbf{B}), \operatorname{ER} \beta\left(\mathbf{A}^{\prime}, \mathbf{B}\right.$ ') or AR (A", B") in the amygdala of male (A, $\mathbf{A}^{\prime}, \mathbf{A}$ ") and female (B, B', B") guinea pigs. Note, that a part of neurons that were immunopositive for $\mathrm{CB}$ were also $\mathrm{ER} \beta+\left(\mathbf{A}^{\prime}, \mathbf{B}^{\prime}\right)$ or $\mathrm{AR}+$ (A”, B"), but virtually none of them were $\mathrm{ER} \alpha+(\mathbf{A}, \mathbf{B}) . L A$ lateral nucleus, $B M$ basomedial nucleus, $M E d$ dorsal part of medial nucleus. Scale bar $50 \mu \mathrm{m}$ in B" (applies to all sections)
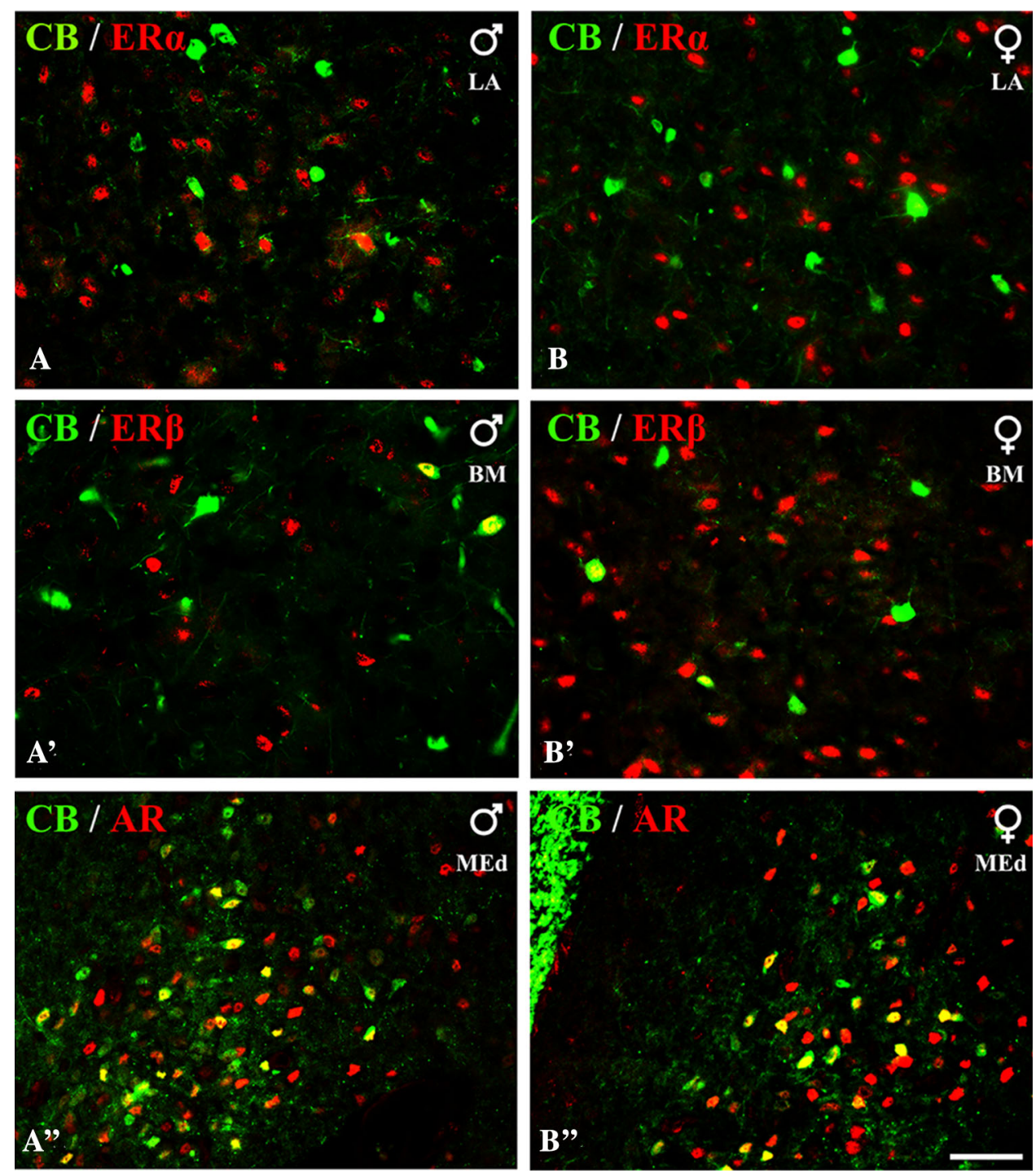

were rarely observed in more anterior portions of the nucleus. However, approximately one-third of PV + cells co-expressed ER $\beta$ within the periamygdaloid cortex and posterior cortical nucleus.

\section{Calretinin neurons}

In contrast to $\mathrm{CB}+$ and $\mathrm{PV}+$ neurons, $\mathrm{CR}+$ cells often coexpressed $\mathrm{ER} \alpha$, but these cells almost never co-expressed ER $\beta$ (Table 5; Fig. 6). Moreover, across diverse regions of the amygdala, there were also dispersed $\mathrm{CR}+$ neurons immunoreactive to AR (Table 5; Fig. 6). Within the lateral nucleus, approximately $20 \%$ of $\mathrm{CR}+$ neurons co-expressed $\mathrm{ER} \alpha$. Within the basolateral, nucleus the density of ER $\alpha+$ cells was low, so the percentage of $\mathrm{CR}+$ neurons co-expressing $\mathrm{ER} \alpha$ was one-third of that in the lateral nucleus. Within the basomedial and medial nuclei more than onethird of $\mathrm{CR}+$ neurons co-expressed $\mathrm{ER} \alpha$, and one quarter of such $\mathrm{CR}+/ \mathrm{ER} \alpha+$ cells were observed within cortical nuclei. Double-labelled neurons for $\mathrm{CR}$ and $\mathrm{AR}$ were observed within the medial, basomedial and cortical nuclei (Table 5; Fig. 6). In the medial and basomedial nuclei approximately 16 and $7 \%$ of $\mathrm{CR}+$ neurons co-expressed $\mathrm{AR}$, respectively. In the cortical nuclei less than $5 \%$ of $\mathrm{CR}+$ cells were AR+.

Statistical evaluation of numbers of cells expressing various calcium-binding proteins, cells double-labelled for both calcium-binding proteins and steroid receptors, as well as percentages of double-labelled cells indicated the sex diversified sensitivity of various amygdala regions to sex hormones. For example, the lateral and basomedial nuclei are mostly controlled by oestrogens via PV+ neurons using ER $\beta$ and $C R+$ cells using ER $\alpha$. Such impact is stronger in females (Tables 4,5 ). On the other hand, the medial nucleus is mostly controlled by androgens via $\mathrm{CB}+$ and $\mathrm{CR}+$ neurons using $\mathrm{AR}$ and by oestrogens via $\mathrm{CR}+$ 
Fig. 4 Representative colour photomicrographs illustrating the anatomical relationships between neurons expressing $\mathrm{CB}$ and PV (a), CB and CR (b), SOM and ER $\beta$ (c) and SOM and AR $(\mathbf{d}-\mathbf{f})$ in the amygdala in the guinea pig. Boxed region in $\mathbf{d}$ is shown at higher magnification in e. Note, extensive colocalization of $\mathrm{CB}$ with $\mathrm{PV}$ (a) and the lack of coexpression of $\mathrm{CB}$ with $\mathrm{CR}$ in the same neurons (b). Note, also that SOM and ER $\beta$ do not coexist in the same neurons (c) while $\mathrm{SOM}+$ neurons were often simultaneously $\mathrm{AR}+(\mathbf{d}-$ f). $B L$ basolateral nucleus, $L A$ lateral nucleus, $B M$ basomedial nucleus, $M E d$ dorsal part of medial nucleus. Scale bar $100 \mu \mathrm{m}(\mathbf{a}-\mathbf{c}), 75 \mu \mathrm{m}$ (d) and $25 \mu \mathrm{m}(\mathbf{e}-\mathbf{f})$
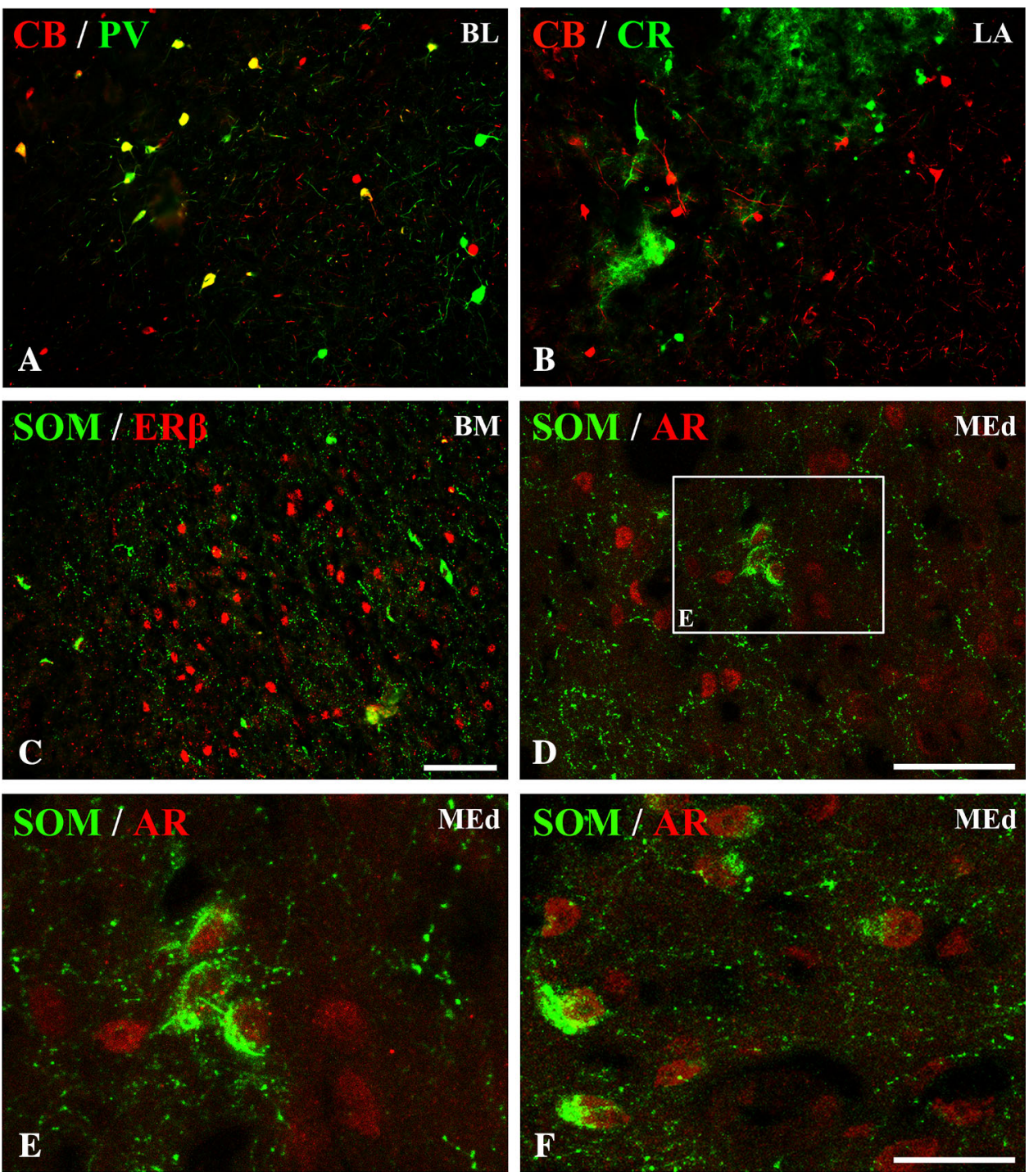

neurons using ER $\alpha$. In both these cases, such influence is stronger in males (Tables 2, 5).

\section{Discussion}

To the best of our knowledge, the present study describes for the first time a systematic analysis of relationships between populations of $\mathrm{CB}+, \mathrm{PV}+$ and $\mathrm{CR}+$ neurons, which form in the amygdala main subsets of GABA+ system and neurons bearing steroid receptors such as $\mathrm{ER} \alpha$ or $\mathrm{ER} \beta$ or $\mathrm{AR}$. The results show that in the amygdala of male and female guinea pig, subpopulations of the $\mathrm{CB}+$ and $\mathrm{PV}+$ neurons co-express $\mathrm{ER} \beta$, while many of the $\mathrm{CR}+$ neurons co-express $\mathrm{ER} \alpha$. In addition, in the medial nucleus and some other neighbouring regions there are also subpopulations of $\mathrm{CB}+$ and $\mathrm{CR}+$ neurons which co-express AR. The localization of ER $\alpha$,
ER $\beta$ or AR within subsets of GABAergic interneurons across diverse amygdaloid regions suggests that steroid hormones may exert a significant influence over local neuronal activity by directly modulating inhibitory tone. The control of inhibitory tone may be a mechanism whereby oestrogen and androgen modulate amygdalar processing in a sex-specific manner. Moreover, as the numbers of $\mathrm{CB}+, \mathrm{PV}+$ and $\mathrm{CR}+$ neurons (Równiak et al. 2015) and the numbers of such cells co-expressing steroid receptors (present results) are sexually dimorphic in various nuclei of the guinea pig amygdala, sensitivity to sex hormones and their impact on many regions may substantially differ in male and female subjects. Thus, $\mathrm{GABA}+$ neurons co-expressing $\mathrm{CB}+, \mathrm{PV}+$ or $\mathrm{CR}+$ provide a precisely designed inhibitory interface which is steroid-sensitive and sexually dimorphic. This interface could be the natural basis for sex-specific processing in the amygdala. 
Fig. 5 Representative colour photomicrographs illustrating the anatomical relationships between $\mathrm{PV}+$ neurons and nuclei immunoreactive for $\mathrm{ER} \alpha$ $(\mathbf{A}, \mathbf{B}), \operatorname{ER} \beta\left(\mathbf{A}^{\prime}, \mathbf{B}^{\prime}\right)$ or $\mathrm{AR}$ (A", B") in the amygdala of male (A, $\mathbf{A}^{\prime}, \mathbf{A}$ ") and female (B, B', B") guinea pigs. Note, extensive co-localization of $\mathrm{PV}+$ neurons with $\operatorname{ER} \beta\left(\mathbf{A}^{\prime}, \mathbf{B}^{\prime}\right)$ but not $\mathrm{ER} \alpha(\mathbf{A}, \mathbf{B})$ or $\mathrm{AR}(\mathbf{A}$, B”). AHA amygdalohippocampal area, $B M$ basomedial nucleus, $\mathrm{CO}$ Cortical nucleus. Scale bar $50 \mu \mathrm{m}$ in B" (applies to all sections)


The present results demonstrate that in the amygdala of the guinea pig, subpopulations of $\mathrm{CB}+, \mathrm{PV}+$ and $\mathrm{CR}+$ neurons are oestrogen or androgen-sensitive as many of these cells co-express ER $\alpha$, ER $\beta$ or AR. The patterns of coexpression are similar in both sexes. However, these patterns are quite different in the "cortex-like" nuclei (the cortical and basolateral amygdala) and "striatum-pallidumlike" nuclei (the central and medial amygdala). In the "cortex-like" regions, $\mathrm{CB}+, \mathrm{PV}+$ and $\mathrm{CR}+$ neurons use mostly oestrogen receptors, and the pattern of co-expression is similar to relationships observed in the cerebral cortex (Blurton-Jones and Tuszynski 2002; Kritzer 2002). In the "striatum-pallidum-like" nuclei $\mathrm{PV}+$ neurons are not present, while $\mathrm{CB}+$ and $\mathrm{CR}+$ cells are much more influenced by androgens. However, there are no data for comparisons in the available literature. As the amygdala is composed of "cortex-like" and "striatum-pallidum-like" nuclei (Swanson and Petrovich 1998), one important fact should be kept in mind. In the "cortex-like" regions, most projection neurons (pyramidal and semi-pyramidal cells) use glutamate as a fast, excitatory neurotransmitter (McDonald 1996), whereas, in contrast, many projection cells of the "striatum-pallidum-like" nuclei use GABA as a fast, inhibitory neurotransmitter (Swanson and Petrovich 1998; Saha et al. 2000; Seo et al. 2016). In the "cortexlike" regions, GAD is expressed in interneurons (McDonald 1985; Pitkänen and Amaral 1994), whereas in the "striatum-pallidum-like" nuclei, it is often expressed in projection neurons (Swanson and Petrovich 1998; Saha et al. 2000; Seo et al. 2016). The finding that substantial subpopulations of $\mathrm{PV}+$ neurons and small subsets of $\mathrm{CB}+$ neurons in the amygdala of the guinea pig co-express ER $\beta$, while these cells almost never co-express ER $\alpha$ coincide well with some previous studies on the "cortex-like" amygdala (Blurton-Jones and Tuszynski 2002; Perez et al. 2004) and cerebral cortex (Kritzer 2002) of the rat. For 
Fig. 6 Representative colour photomicrographs illustrating the anatomical relationships between $\mathrm{CR}+$ neurons and nuclei immunoreactive for $\mathrm{ER} \alpha$ $(\mathbf{A}, \mathbf{B}), \operatorname{ER} \beta\left(\mathbf{A}^{\prime}, \mathbf{B}\right.$ ') or AR (A", B") in the amygdala of male (A, $\mathbf{A}^{\prime}, \mathbf{A}^{\prime}$ ) $)$ and female (B. B', B") guinea pigs. Note, extensive co-localization of $\mathrm{CR}+$ neurons with $\mathrm{ER} \alpha(\mathbf{A}, \mathbf{B})$, but not $\operatorname{ER} \beta$ (A', B'). Note, also that some $\mathrm{CR}+$ neurons were simultaneously

immunonoreactive for AR (A", B"). $B M$ basomedial nucleus, $C O$ cortical nucleus, $M E d$ dorsal part of medial nucleus. Scale bar $50 \mu \mathrm{m}$ in B" (applies to all sections)
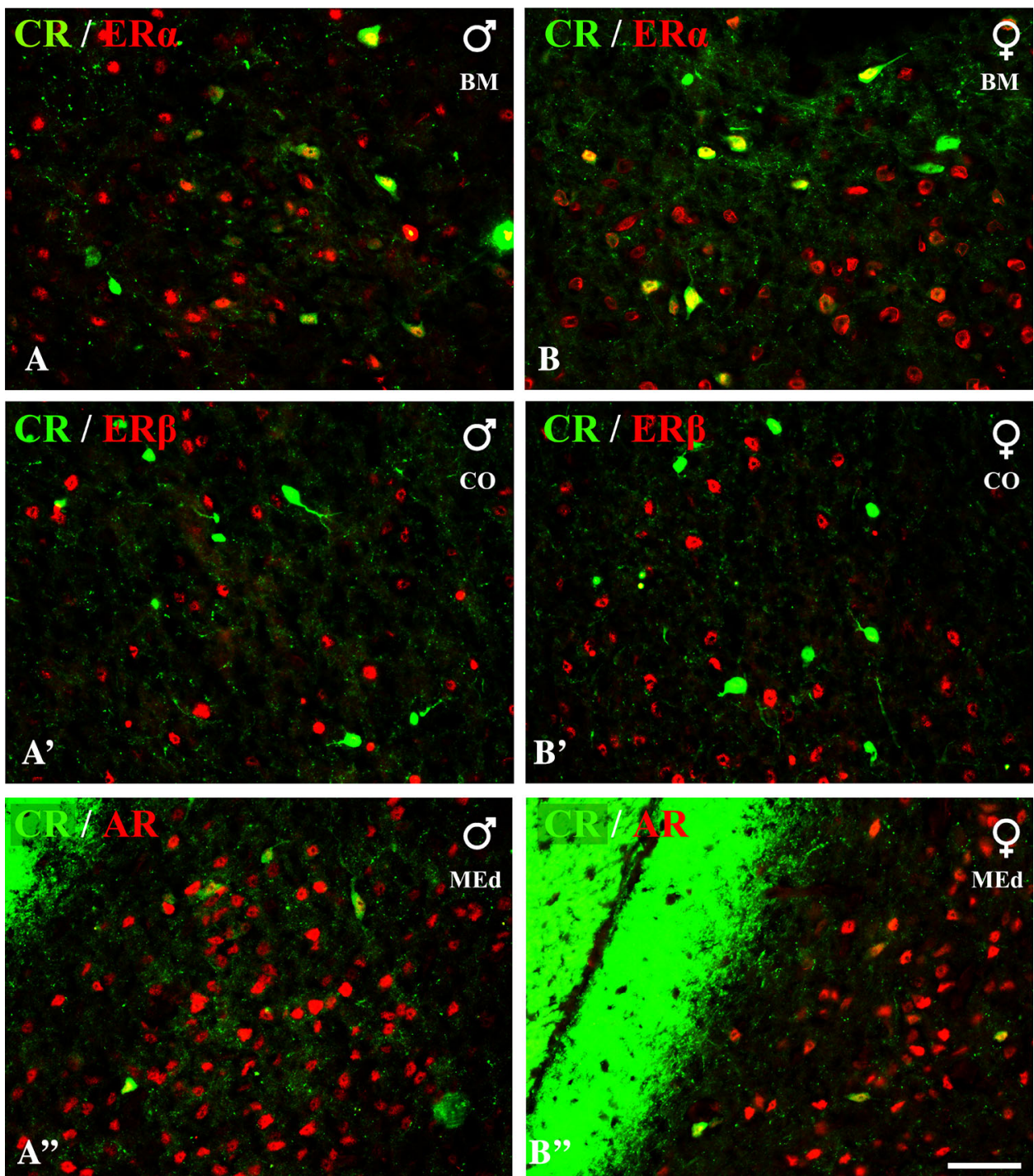

example, extensive co-localization of $\mathrm{PV}+$ neurons with $\mathrm{ER} \beta$ was reported in this species in the lateral and basomedial nuclei of the amygdala (Blurton-Jones and Tuszynski 2002) and sensorimotor and association areas of the cerebral cortex (Blurton-Jones and Tuszynski 2002; Kritzer 2002). The co-expression of $\mathrm{CB}+$ neurons with $\mathrm{ER} \beta$ in the sensorimotor and association cortices was rather limited. However, in the piriform and enthorinal cortices, such co-expression was much more extensive (Kritzer 2002). On the other hand, there is no or very weak co-expression between $\mathrm{CB}+$ or $\mathrm{PV}+$ neurons with $\mathrm{ER} \alpha$ in the amygdala (present results; Perez et al. 2004) and various areas of the cerebral cortex (Perez et al. 2004; Kritzer 2002). The present results also demonstrate that substantial populations of $\mathrm{CR}+$ neurons in the amygdala of the guinea pig co-express $\mathrm{ER} \alpha$, while these cells were almost without exception immunonegative for ER $\beta$. These findings are in agreement with observations in the juvenile rat cerebral cortex, which revealed substantial overlap between $\mathrm{CR}+$ and $\mathrm{ER} \alpha+$ immunoreactivity but virtually no co-localization of $\mathrm{CR}+$ and $\mathrm{ER} \beta+$ immunolabelling (Hayashi et al. 2001; Kritzer 2005). The cells double-labelled for CR and $\mathrm{ER} \alpha$ were also described in the adult rat hippocampus (Nakamura and McEwen 2005). Finally, the present results demonstrate that in the medial nucleus and in some other neighbouring regions, there are also subpopulations of $\mathrm{CB}+$ and $\mathrm{CR}+$ neurons which co-express $\mathrm{AR}$. Data concerning relationships between $\mathrm{CB}+$ neurons and $\mathrm{AR}$ in the amygdala are not as yet available. In the cerebral cortex AR is mostly present in the pyramidal neurons, and in the most cortical areas virtually none of the non-pyramidal $\mathrm{CB}+$ or $\mathrm{PV}+$ neurons were found to be immunoreactive for AR (Kritzer 2004). Only in the proisocortical areas of the piriform and entorhinal cortices, many of the nonpyramidal $\mathrm{CB}+$ or $\mathrm{PV}+$ cells were simultaneously $\mathrm{AR}+$ (Kritzer 2004). Data concerning relationships between 
$\mathrm{CR}+$ neurons and $\mathrm{AR}$ in the amygdala or cerebral cortex are not yet available.

The present results demonstrate that there is strict cellular separation of ER $\beta$ in $\mathrm{CB}+$ and/or PV+ neurons and $\mathrm{ER} \alpha$ in $\mathrm{CR}+$ cells. In contrast, $\mathrm{AR}$ is expressed in non-overlapping subpopulations of $\mathrm{CB}+$ and $\mathrm{CR}+$ cells, because $\mathrm{CR}$ and $\mathrm{CB}$ were not co-localized in amygdala neurons of the guinea pig. Such separaration of ER $\alpha, E R \beta$ or AR within subsets of nonoverlapping subpopulations of GABA+ interneurons does not seem to be accidental, and this suggests that these steroidsensitive subsets form a kind of precisely designed interface for sex hormones' actions. For example, there is no or very little overlap in adult life between immunoreactivity for ER $\beta$ and ER $\alpha$ in any major region of the cortex, hippocampus or amygdala (Kritzer 2002; Perez et al. 2004), although there are brain regions where such co-existence exists (Gréco et al. 2001). There is also no or very little overlap between CR+ cells either with $\mathrm{CB}+$ or $\mathrm{PV}+$ neurons in the cortex, hippocampus or amygdala (present results, and Miettinen et al. 1992; Mascagni et al. 2009). However, in all these areas there is extensive co-localization of CB and PV in the same neurons (present results, and Mascagni et al. 2009). Moreover, there are intriguing parallels in the development of ER $\beta+$ and $\mathrm{PV}+$ neurons on the one hand and $\mathrm{ER} \alpha+$ and $\mathrm{CR}+$ cells on the other, suggesting that the cellular separation observed in adult life is established during brain development (Kritzer 2005). Specifically, in the postnatal rat cerebrum, like ER $\beta+$ cells, $\mathrm{PV}+$ neurons are identified initially in low numbers around PND 7 (7th day of postnatal life), and from that time steadily increase in number and density to reach mature patterns of labelling by the end of the third postnatal week (Alcántara et al. 1993; Solbach and Celio 1991; Sánchez et al. 1992; Hof et al. 1999). In contrast, like ER $\alpha+$ cells, $\mathrm{CR}+$ neurons peak in density early, at about PND 7, transiently include large numbers of pyramidal and non-pyramidal cells, and sharply decrease from peak densities in early postnatal life to much lower, near-adult values by PND 15-21 (Fonseca et al. 1995; Schierle et al. 1997; Hof et al. 1999). Finally, double-labelling studies in the rat and monkey indicated that in the adult mammalian amygdala, there are at least three non-overlapping subpopulations of GABA+ interneurons: (1) PV+ neurons (most of which also contain $\mathrm{CB}$ ); (2) SOM+ neurons (most of which also contain $\mathrm{CB}$ and/or neuropeptide Y); and (3) CR+ neurons (most of which also contain cholecystokinin and/or vasoactive intestinal polypeptide) (McDonald and Mascagni 2001, 2002; Mascagni and McDonald 2003; Mascagni et al. 2009). Interestingly, the present results indicate that the first population uses ER $\beta$ to respond to sex hormones. The second one is endowed with AR. The third subpopulation co-expresses usually ER $\alpha$, but some of these neurons also utilize AR. It is worth mentioning that the present work was done in the guinea pig, which could be a good model system for studying brain sexual dimorphism, as well as neuroendocrine and developmental processes because of the many similarities to primates and humans (Wallen and Baum 2002; Bartesaghi and Severi 2004, Kaiser and Sachser 2005). As the results in the guinea pig are quite similar to available data obtained from the rat (Blurton-Jones and Tuszynski 2002) and monkey (Perez et al. 2004), it seems that in the amygdala the co-expression patterns of neurons containing calciumbinding proteins and steroid receptors may be similar across various mammalian species.

The present results seem to be very interesting in the light of synaptic studies which indicated that $\mathrm{PV}+, \mathrm{CB}+$ and $\mathrm{CR}+$ neurons perform quite different roles in the inhibitory mechanism of the amygdala (Muller et al. 2007; Miles et al. 1996; Woodruff and Sah 2007a). It should be added, however, that available data are limited to the "cortex-like" amygdala only. For example, PV+ neurons are considered to be a critical component of the inhibitory circuitry in the basolateral and cortical amygdala, where they form characteristic basket-like plexuses around the unstained somata and cartridges, which represent axo-axonic contacts on initial segments of axons (McDonald and Mascagni 2001; Muller et al. 2005; Woodruff and Sah 2007b). Thus, as in the cortex, many PV+ interneurons in both the rodent and primate "cortex-like" amygdala appear to be basket or chandelier cells that provide a strong perisomatic inhibition of local pyramidal neurons (Pitkänen and Amaral 1993; Sorvari et al. 1995, 1996; Woodruff and Sah 2007a, b). Such inhibition is considered to control the output, most notably the synchrony of action potentials of large principal cell populations (Cobb et al. 1995; Miles et al. 1996). Taking into account that many $\mathrm{PV}+$ neurons in the amygdala coexpress ER $\beta$ (present results, and Blurton-Jones and Tuszynski 2002), and that the numbers of these cells in various amygdaloid nuclei are sexually dimorphic (Równiak et al. 2015; Stefanova et al. 1997), the mechanism described above may be strongly modulated by circulating steroid hormones and sex-specific. $\mathrm{CB}+$ neurons perform a dual role in the intrinsic inhibitory mechanism of the amygdala. In rodents (but not primates) some of them appear to be basket cells, which provide a strong perisomatic inhibition of local pyramidal neurons, and such cells co-express PV but do not contain somatostatin and/or neuropeptide Y (Pitkänen and Amaral 1993; Sorvari et al. 1995, 1996; Woodruff and Sah 2007a, b). The other CB+ neurons are considered as dendrite-targeting interneurons, providing a robust innervation of dendrites in the rat and primate amygdala (Mascagni et al. 2009). Such neurons contain somatostatin and/or neuropeptide Y (but not PV) (McDonald and Mascagni 2002; Muller et al. 2007), and are responsible for the control of the efficacy and plasticity of inputs from specific sources that terminate in the same dendritic domain (Cobb et al. 1995; Miles et al. 1996). Interestingly, it seems probable that 
the double-labelled $\mathrm{CB}+/ \mathrm{ER} \beta+$ neurons observed in the present study are those $\mathrm{CB}+$ cells which contain $\mathrm{PV}$. On the other hand, $\mathrm{CB}+/ \mathrm{AR}+$ neurons are most probably those $\mathrm{CB}+$ cells which co-express somatostatin. Thus, both subpopulations of $\mathrm{CB}+$ neurons and both mechanisms described above may be modulated by circulating steroid hormones and sex-specific. There are no detailed synaptic studies on the amygdala concerned with $\mathrm{CR}+$ neurons. However, such studies in the neocortex revealed that $\mathrm{CR}+$ neurons are mostly dendrite-targeting, and their buttons typically innervate dendritic shafts, and less often dendritic spines or somata (Meskenaite 1997). Moreover, at least in some cortical areas and layers, $\mathrm{CR}+$ neurons innervate preferentially other GABA+ neurons (Melchitzky and Lewis 2008), and by inhibiting other classes of inhibitory interneurons they may exert a significant disinhibitory effect on the pyramidal neurons (Meskenaite 1997; Gonchar and Burkhalter 1999). Analogous relationships were also described in the hippocampus, where $\mathrm{CR}+$ interneurons were found to be specialized to control other interneuronal types (Gulyás et al. 1996). Taking into account that many $\mathrm{CR}+$ neurons in the amygdala co-express $\mathrm{ER} \alpha$ or $\mathrm{AR}$ (present results), the mechanisms described above may be strongly modulated by both oestrogen or testosterone, and thus sex-specific.

The present results and some other studies (Krężel et al. 2001; Tan et al. 2012; Blurton-Jones and Tuszynski 2002) provide evidence that there is a relationship between steroid hormone receptors and inhibitory tone in the amygdala. Thus, the question arises what may be the functional significance of such a relationship. There are several lines of evidence that modulation of inhibitory tone by oestrogen and/or androgen via steroid receptors on GABAergic cells may be important for proper amygdala physiology, and any alterations in such modulation may lead to various psychiatric disorders, which differentially affect men and women (prevalence, severity) (Krężel et al. 2001; Kinrys and Wygant 2005). For example, studies in ER $\beta$ knock-out mice revealed that mutant females displayed increased anxiety and/or depression-like behaviour associated with a reduced threshold for the induction of synaptic plasticity in the basolateral amygdala (Krężel et al. 2001). A reduced threshold in this structure could result in exaggerated responses to normally innocuous stimuli or environments, a characteristic feature of fear and anxiety disorders. Whether a reduction of GABA responses in the basolateral amygdala is the mechanism by which anxiety is increased in ER $\beta$ mutant mice remains to be tested, but some evidence indicates that pharmacological manipulation of GABA type A receptors in wild type mice can mimic some of the effects of ER $\beta$ null mutation (Krężel et al. 2001). Moreover, selective ER $\beta$ agonists typically exert potent anxiolytic activity (Lund et al. 2005; Oyola et al. 2012).
Such anxiolytic effects are mediated by the cortex and hippocampus, and most probably also by the basolateral amygdala, by elevation of GABAergic inhibitory signalling and reduction of glutamatergic excitatory drive (Tan et al. 2012). On the other hand, male ER $\alpha$ knock-out mice display reduced aggression (Ogawa et al. 1997, 1998), while selective $\mathrm{ER} \alpha$ agonists typically elevate anxiety and/or aggression (Nomura et al. 2002). All these data from ER $\beta$ and $\mathrm{ER} \alpha$ knock-out mice are in accordance with recent physiological studies (Adhikari et al. 2015; Hong et al. 2014) and the present description of ER $\alpha, E R \beta$ and/or AR enrichment in several amygdala nuclei. For example, the basomedial nucleus is the region in the amygdala, which is directly engaged in anxiolysis, however, the medial and cortical nuclei cannot be excluded as well (Adhikari et al. 2015). Interestingly, in all these nuclei, ER $\beta$ is very abundant according to present results. On the other hand, in the medial nucleus, which is especially rich in ER $\alpha$ and other steroid receptors, there are many aggression-promoting GABAergic neurons (Hong et al. 2014).

\section{Conclusions}

The results of the present study provide evidence that in the amygdala of the guinea pig subpopulations of $\mathrm{CB}+$ and $\mathrm{PV}+$ neurons co-express ER $\beta$, while many of $\mathrm{CR}+$ neurons co-express ER $\alpha$. In addition, in the selected nuclei, there are also subpopulations of $\mathrm{CB}+$ and $\mathrm{CR}+$ neurons which co-express AR. The localization of $\mathrm{ER} \alpha, \mathrm{ER} \beta$ or AR within subsets of GABAergic interneurons across diverse amygdaloid regions suggests that steroid hormones may exert a significant influence over local neuronal activity by directly modulating inhibitory tone. The control of inhibitory tone may be one of the mechanisms whereby oestrogen and androgen could modulate amygdala processing in a sex-specific manner. Another mechanism may be thorough steroid-sensitive projection neurons, which are most probably located in the medial and central nuclei.

Acknowledgements I would like to thank Dr. Krystyna BogusNowakowska and Dr. Barbara Wasilewska from Department of Comparative Anatomy, Faculty of Biology and Biotechnology, University of Warmia and Mazury for independent cell counts necessary for inter-rater reliability tests. I would like to thank also Dr. Katarzyna Głowacka from Department of Plant Physiology, Genetics and Biotechnology, Faculty of Biology and Biotechnology, University of Warmia and Mazury for help with the confocal microscopy.

Open Access This article is distributed under the terms of the Creative Commons Attribution 4.0 International License (http://crea tivecommons.org/licenses/by/4.0/), which permits unrestricted use, distribution, and reproduction in any medium, provided you give appropriate credit to the original author(s) and the source, provide a link to the Creative Commons license, and indicate if changes were made. 


\section{References}

Adhikari A, Lerner TN, Finkelstein J et al (2015) Basomedial amygdala mediates top-down control of anxiety and fear. Nature 527:179-185. doi:10.1038/nature 15698

Airaksinen MS, Eilers J, Garaschuk O et al (1997) Ataxia and altered dendritic calcium signaling in mice carrying a targeted null mutation of the calbindin D28k gene. Proc Natl Acad Sci USA 94:1488-1493

Alcántara S, Ferrer I, Soriano E (1993) Postnatal development of parvalbumin and calbindin D28K immunoreactivities in the cerebral cortex of the rat. Anat Embryol (Berl) 188:63-73

Bartesaghi R, Severi S (2004) Effects of early environment on field CA2 pyramidal neurons in the guinea-pig. Neuroscience 123:703-714

Barth C, Villringer A, Sacher J (2015) Sex hormones affect neurotransmitters and shape the adult female brain during hormonal transition periods. Front Neurosci. doi:10.3389/fnins. 2015.00037

Baum MJ (2009) Sexual differentiation of pheromone processing: links to male-typical mating behavior and partner preference. Horm Behav 55:579-588

Bekker MHJ, van Mens-Verhulst J (2007) Anxiety disorders: sex differences in prevalence, degree, and background, but genderneutral treatment. Gend Med 4(Suppl B):S178-S193

Blurton-Jones M, Tuszynski MH (2002) Estrogen receptor-beta colocalizes extensively with parvalbumin-labeled inhibitory neurons in the cortex, amygdala, basal forebrain, and hippocampal formation of intact and ovariectomized adult rats. J Comp Neurol 452:276-287. doi:10.1002/cne.10393

Buffalari DM, See RE (2010) Amygdala mechanisms of Pavlovian psychostimulant conditioning and relapse. Curr Top Behav Neurosci 3:73-99. doi:10.1007/7854_2009_18

Canli T, Desmond JE, Zhao Z, Gabrieli JDE (2002) Sex differences in the neural basis of emotional memories. Proc Natl Acad Sci 99:10789-10794. doi:10.1073/pnas.162356599

Cobb SR, Buhl EH, Halasy K et al (1995) Synchronization of neuronal activity in hippocampus by individual GABAergic interneurons. Nature 378:75-78. doi:10.1038/378075a0

Córdoba Montoya DA, Carrer HF (1997) Estrogen facilitates induction of long term potentiation in the hippocampus of awake rats. Brain Res 778:430-438

Davidson RJ, Pizzagalli D, Nitschke JB, Putnam K (2002) Depression: perspectives from affective neuroscience. Annu Rev Psychol 53:545-574. doi:10.1146/annurev.psych.53.100901. 135148

Drexel M, Preidt AP, Kirchmair E, Sperk G (2011) Parvalbumin interneurons and calretinin fibers arising from the thalamic nucleus reuniens degenerate in the subiculum after kainic acidinduced seizures. Neuroscience 189:316-329. doi:10.1016/j. neuroscience.2011.05.021

Fagergren P, Hurd YL (1999) Mesolimbic gender differences in peptide CART mRNA expression: effects of cocaine. NeuroReport 10:3449-3452

Fonseca M, Del Río JA, Martínez A et al (1995) Development of cairetinin immunoreactivity in the neocortex of the rat. J Comp Neurol 361:177-192. doi:10.1002/cne.903610114

Foy MR (2001) 17beta-estradiol: effect on CA1 hippocampal synaptic plasticity. Neurobiol Learn Mem 76:239-252. doi:10.1006/nlme. 2001.4018

Frye CA, Koonce CJ, Edinger KL et al (2008) Androgens with activity at estrogen receptor beta have anxiolytic and cognitiveenhancing effects in male rats and mice. Horm Behav 54:726-734. doi:10.1016/j.yhbeh.2008.07.013
Gonchar Y, Burkhalter A (1999) Connectivity of GABAergic calretinin-immunoreactive neurons in rat primary visual cortex. Cereb Cortex N Y N 1991 9:683-696

Gréco B, Allegretto EA, Tetel MJ, Blaustein JD (2001) Coexpression of ER $\beta$ with $E R \alpha$ and progestin receptor proteins in the female rat forebrain: effects of estradiol treatment. Endocrinology 142:5172-5181

Gruene TM, Flick K, Stefano A et al (2015) Sexually divergent expression of active and passive conditioned fear responses in rats. Elife 4:e11352

Gulyás AI, Hájos N, Freund TF (1996) Interneurons containing calretinin are specialized to control other interneurons in the rat hippocampus. J Neurosci 16:3397-3411

Hamann S (2005) Sex differences in the responses of the human amygdala. Neuroscientist 11:288-293

Hayashi S, Hayashi H, Ueda H, Papadopoulos GC (2001) Analysis of transient expression of estrogen receptor- $\alpha$ in newborn rat primary auditory cortex. Horm Behav 40:191-195. doi:10.1006/ hbeh.2001.1693

Herbison AE, Fénelon VS (1995) Estrogen regulation of GABAA receptor subunit mRNA expression in preoptic area and bed nucleus of the stria terminalis of female rat brain. J Neurosci 15:2328-2337

Herbison AE, Augood SJ, Simonian SX, Chapman C (1995) Regulation of GABA transporter activity and mRNA expression by estrogen in rat preoptic area. J Neurosci 15:8302-8309

Hof PR, Glezer II, Condé F et al (1999) Cellular distribution of the calcium-binding proteins parvalbumin, calbindin, and calretinin in the neocortex of mammals: phylogenetic and developmental patterns. J Chem Neuroanat 16:77-116

Hong W, Kim D-W, Anderson DJ (2014) Antagonistic control of social versus repetitive self-grooming behaviors by separable amygdala neuronal subsets. Cell 158:1348-1361. doi:10.1016/j. cell.2014.07.049

Kaiser S, Sachser N (2005) The effects of prenatal social stress on behaviour: mechanisms and function. Neurosci Biobehav Rev 29:283-294. doi:10.1016/j.neubiorev.2004.09.015

Kemppainen S, Pitkänen A (2000) Distribution of parvalbumin, calretinin, and calbindin- $\mathrm{D}(28 \mathrm{k})$ immunoreactivity in the rat amygdaloid complex and colocalization with gamma-aminobutyric acid. J Comp Neurol 426:441-467

Kevetter GA, Winans SS (1981) Connections of the corticomedial amygdala in the golden hamster. I. Efferents of the "vomeronasal amygdala". J Comp Neurol 197:81-98

Kinrys G, Wygant LE (2005) Anxiety disorders in women: does gender matter to treatment? Rev Bras Psiquiatr Sao Paulo Braz 1999 27(Suppl 2):S43-S50. doi:10.1590/S1516-44462005000600003

Kiss J, Csaba Z, Csáki Á, Halász B (2013) Demonstration of estrogen receptor $\alpha$ protein in glutamatergic (vesicular glutamate transporter 2 immunoreactive) neurons of the female rat hypothalamus and amygdala using double-label immunocytochemistry. Exp Brain Res 226:595-602. doi:10.1007/s00221-013-3474-8

Krężel W, Dupont S, Krust A et al (2001) Increased anxiety and synaptic plasticity in estrogen receptor $\beta$-deficient mice. Proc Natl Acad Sci 98:12278-12282

Kritzer MF (2002) Regional, laminar, and cellular distribution of immunoreactivity for $\mathrm{ER} \alpha$ and $\mathrm{ER} \beta$ in the cerebral cortex of hormonally intact, adult male and female rats. Cereb Cortex $12: 116-128$

Kritzer M (2004) The distribution of immunoreactivity for intracellular androgen receptors in the cerebral cortex of hormonally intact adult male and female rats: localization in pyramidal neurons making corticocortical connections. Cereb Cortex 14:268-280. doi:10.1093/cercor/bhg 127 
Kritzer MF (2005) Regional, laminar and cellular distribution of immunoreactivity for ER in the cerebral cortex of hormonally intact, postnatally developing male and female rats. Cereb Cortex 16:1181-1192. doi:10.1093/cercor/bhj059

LeDoux JE (1994) The amygdala: contributions to fear and stress. Semin Neurosci 6:231-237. doi:10.1006/smns.1994.1030

LeDoux J (2003) The emotional brain, fear, and the amygdala. Cell Mol Neurobiol 23:727-738

Lephart ED (1996) A review of brain aromatase cytochrome P450. Brain Res Brain Res Rev 22:1-26

Lund TD, Rovis T, Chung WCJ, Handa RJ (2005) Novel actions of estrogen receptor- $\beta$ on anxiety-related behaviors. Endocrinology 146:797-807. doi:10.1210/en.2004-1158

Martel KL, Baum MJ (2009) A centrifugal pathway to the mouse accessory olfactory bulb from the medial amygdala conveys gender-specific volatile pheromonal signals. Eur J Neurosci 29:368-376

Mascagni F, McDonald AJ (2003) Immunohistochemical characterization of cholecystokinin containing neurons in the rat basolateral amygdala. Brain Res 976:171-184

Mascagni F, Muly EC, Rainnie DG, McDonald AJ (2009) Immunohistochemical characterization of parvalbumin-containing interneurons in the monkey basolateral amygdala. Neuroscience 158:1541-1550. doi:10.1016/j.neuroscience.2008.11.017

McDonald AJ (1985) Immunohistochemical identification of gammaaminobutyric acid-containing neurons in the rat basolateral amygdala. Neurosci Lett 53:203-207

McDonald AJ (1989) Coexistence of somatostatin with neuropeptide $\mathrm{Y}$, but not with cholecystokinin or vasoactive intestinal peptide, in neurons of the rat amygdala. Brain Res 500:37-45

McDonald AJ (1996) Glutamate and aspartate immunoreactive neurons of the rat basolateral amygdala: colocalization of excitatory amino acids and projections to the limbic circuit. J Comp Neurol 365:367-379. doi:10.1002/(SICI)10969861(19960212)365:3<367:AID-CNE3>3.0.CO;2-2

McDonald AJ, Mascagni F (2001) Colocalization of calcium-binding proteins and GABA in neurons of the rat basolateral amygdala. Neuroscience 105:681-693

McDonald AJ, Mascagni F (2002) Immunohistochemical characterization of somatostatin containing interneurons in the rat basolateral amygdala. Brain Res 943:237-244

McDonald AJ, Mascagni F (2004) Parvalbumin-containing interneurons in the basolateral amygdala express high levels of the $\alpha 1$ subunit of the GABAA receptor. J Comp Neurol 473:137-146. doi:10.1002/cne.20101

McDonald AJ, Mascagni F, Zaric V (2012) Subpopulations of somatostatin-immunoreactive non-pyramidal neurons in the amygdala and adjacent external capsule project to the basal forebrain: evidence for the existence of GABAergic projection neurons in the cortical nuclei and basolateral nuclear complex. Front Neural Circuits 6:46. doi:10.3389/fncir.2012.00046

Melchitzky DS, Lewis DA (2008) Dendritic-targeting GABA neurons in monkey prefrontal cortex: comparison of somatostatin- and calretinin-immunoreactive axon terminals. Synap N Y N 62:456-465. doi:10.1002/syn.20514

Meskenaite V (1997) Calretinin-immunoreactive local circuit neurons in area 17 of the cynomolgus monkey, Macaca fascicularis. J Comp Neurol 379:113-132

Meszar Z, Girard F, Saper CB, Celio MR (2012) The lateral hypothalamic parvalbumin-immunoreactive (PV1) nucleus in rodents. J Comp Neurol 520:798-815. doi:10.1002/cne.22789

Miettinen R, Gulyás AI, Baimbridge KG et al (1992) Calretinin is present in non-pyramidal cells of the rat hippocampus-II. Coexistence with other calcium binding proteins and GABA. Neuroscience 48:29-43
Miles R, Tóth K, Gulyás AI et al (1996) Differences between somatic and dendritic inhibition in the hippocampus. Neuron 16:815-823

Morris JA, Jordan CL, King ZA et al (2008) Sexual dimorphism and steroid responsiveness of the posterodorsal medial amygdala in adult mice. Brain Res 1190:115-121

Moryś J, Berdel B, Kowiański P et al (1999) Relationship of calciumbinding protein containing neurons and projection neurons in the rat basolateral amygdala. Neurosci Lett 259:91-94

Muller JF, Mascagni F, McDonald AJ (2005) Coupled networks of parvalbumin-immunoreactive interneurons in the rat basolateral amygdala. J Neurosci Off J Soc Neurosci 25:7366-7376. doi:10. 1523/JNEUROSCI.0899-05.2005

Muller JF, Mascagni F, McDonald AJ (2007) Postsynaptic targets of somatostatin-containing interneurons in the rat basolateral amygdala. J Comp Neurol 500:513-529. doi:10.1002/cne.21185

Murphy DD, Cole NB, Greenberger V, Segal M (1998) Estradiol increases dendritic spine density by reducing GABA neurotransmission in hippocampal neurons. J Neurosci 18:2550-2559

Nakamura NH, McEwen BS (2005) Changes in interneuronal phenotypes regulated by estradiol in the adult rat hippocampus: a potential role for neuropeptide Y. Neuroscience 136:357-369. doi:10.1016/j.neuroscience.2005.07.056

Nakamura NH, Rosell DR, Akama KT, McEwen BS (2004) Estrogen and ovariectomy regulate mRNA and protein of glutamic acid decarboxylases and cation-chloride cotransporters in the adult rat hippocampus. Neuroendocrinology 80:308-323. doi:10.1159/ 000083657

Nomura M, Durbak L, Chan J et al (2002) Genotype/Age interactions on aggressive behavior in gonadally intact estrogen receptor $\beta$ knockout ( $\beta$ ERKO) male mice. Horm Behav 41:288-296. doi:10.1006/hbeh.2002.1773

Ogawa S, Lubahn DB, Korach KS, Pfaff DW (1997) Behavioral effects of estrogen receptor gene disruption in male mice. Proc Natl Acad Sci USA 94:1476-1481

Ogawa S, Washburn TF, Taylor J et al (1998) Modifications of testosterone-dependent behaviors by estrogen receptor-alpha gene disruption in male mice. Endocrinology 139:5058-5069. doi:10.1210/endo.139.12.6358

Oyola MG, Portillo W, Reyna A et al (2012) Anxiolytic effects and neuroanatomical targets of estrogen receptor- $\beta(\operatorname{ER} \beta)$ activation by a selective ER $\beta$ agonist in female mice. Endocrinology 153:837-846. doi:10.1210/en.2011-1674

Pape H-C, Pare D (2010) Plastic synaptic networks of the amygdala for the acquisition, expression, and extinction of conditioned fear. Physiol Rev 90:419-463. doi:10.1152/physrev.00037.2009

Perez S, Sendera T, Kordower J, Mufson E (2004) Estrogen receptor alpha containing neurons in the monkey forebrain: lack of association with calcium binding proteins and choline acetyltransferase. Brain Res 1019:55-63. doi:10.1016/j.brainres.2004.05.101

Pitkänen A, Amaral DG (1993) Distribution of parvalbumin-immunoreactive cells and fibers in the monkey temporal lobe: the amygdaloid complex. J Comp Neurol 331:14-36. doi:10.1002/ cne. 903310103

Pitkänen A, Amaral DG (1994) The distribution of GABAergic cells, fibers, and terminals in the monkey amygdaloid complex: an immunohistochemical and in situ hybridization study. J Neurosci 14:2200-2224

Rollins BL, King BM (2000) Amygdala-lesion obesity: what is the role of the various amygdaloid nuclei? Am J Physiol Regul Integr Comp Physiol 279:R1348-R1356

Równiak M (2013) The amygdala in the guinea pig is sexually dimorphic-A morphometric study. Brain Res 1524:44-53. doi:10.1016/j.brainres.2013.06.005

Równiak M, Robak A, Bogus-Nowakowska K et al (2008) Somatostatin-like immunoreactivity in the amygdala of the pig. Folia 
Histochem Cytobiol 46:229-238. doi:10.2478/v10042-0080035-2

Równiak M, Bogus-Nowakowska K, Robak A (2015) The densities of calbindin and parvalbumin, but not calretinin neurons, are sexually dimorphic in the amygdala of the guinea pig. Brain Res 1604:84-97. doi:10.1016/j.brainres.2015.01.048

Sah P, Faber ESL, Lopez De Armentia M, Power J (2003) The amygdaloid complex: anatomy and physiology. Physiol Rev 83:803-834. doi:10.1152/physrev.00002.2003

Saha S, Batten TF, Henderson Z (2000) A GABAergic projection from the central nucleus of the amygdala to the nucleus of the solitary tract: a combined anterograde tracing and electron microscopic immunohistochemical study. Neuroscience 99:613-626

Sánchez MP, Frassoni C, Alvarez-Bolado G et al (1992) Distribution of calbindin and parvalbumin in the developing somatosensory cortex and its primordium in the rat: an immunocytochemical study. J Neurocytol 21:717-736

Schierle GS, Gander JC, D’Orlando C et al (1997) Calretininimmunoreactivity during postnatal development of the rat isocortex: a qualitative and quantitative study. Cereb Cortex 7:130-142. doi:10.1093/cercor/7.2.130

Segovia S, Garcia-Falgueras A, Carrillo B et al (2006) Sexual dimorphism in the vomeronasal system of the rabbit. Brain Res 1102:52-62

Seidlitz L, Diener E (1998) Sex differences in the recall of affective experiences. J Pers Soc Psychol 74:262-271

Seo D-O, Funderburk SC, Bhatti DL et al (2016) A GABAergic projection from the centromedial nuclei of the amygdala to ventromedial prefrontal cortex modulates reward behavior. J Neurosci Off J Soc Neurosci 36:10831-10842. doi:10.1523/ JNEUROSCI.1164-16.2016

Shughrue PJ, Lane MV, Merchenthaler I (1997) Comparative distribution of estrogen receptor-alpha and -beta mRNA in the rat central nervous system. J Comp Neurol 388:507-525

Smith CC, Vedder LC, McMahon LL (2009) Estradiol and the relationship between dendritic spines, NR2B containing NMDA receptors, and the magnitude of long-term potentiation at hippocampal CA3-CA1 synapses. Psychoneuroendocrinology 34(Suppl 1):S130-S142. doi:10.1016/j.psyneuen.2009.06.003

Solbach S, Celio MR (1991) Ontogeny of the calcium binding protein parvalbumin in the rat nervous system. Anat Embryol (Berl) 184:103-124

Sorvari H, Soininen H, Paljärvi L et al (1995) Distribution of parvalbumin-immunoreactive cells and fibers in the human amygdaloid complex. J Comp Neurol 360:185-212. doi:10.1002/ cne. 903600202

Sorvari H, Miettinen R, Soininen H, Pitkänen A (1996) Parvalbuminimmunoreactive neurons make inhibitory synapses on pyramidal cells in the human amygdala: a light and electron microscopic study. Neurosci Lett 217:93-96

Stanić D, Dubois S, Chua HK et al (2014) Characterization of aromatase expression in the adult male and female mouse brain. I. Coexistence with Oestrogen receptors $\alpha$ and $\beta$, and androgen receptors. PLoS One 9:e90451. doi:10.1371/journal.pone. 0090451

Stefanova N, Bozhilova-Patirova A, Ovtscharoff W (1997) Sex differences of parvalbumin-immunoreactive neurons in the rat brain. Biomed Rev 7:91-96

Swaab DF, Chung WCJ, Kruijver FPM et al (2003) Sex differences in the hypothalamus in the different stages of human life. Neurobiol Aging 24:S1-S19

Swanson LW, Petrovich GD (1998) What is the amygdala? Trends Neurosci 21:323-331

Tan X-J, Dai Y-B, Wu W-F et al (2012) Reduction of dendritic spines and elevation of GABAergic signaling in the brains of mice treated with an estrogen receptor ligand. Proc Natl Acad Sci 109:1708-1712. doi:10.1073/pnas.1121162109

Tindal JS (1965) The forebrain of the guinea pig in stereotaxic coordinates. J Comp Neurol 124:259-266. doi:10.1002/cne. 901240210

Wallen K, Baum MJ (2002) Masculinization and defeminization in altricial and precocial mammals: comparative aspects of steroid hormone action. Horm Brain Behav 4:385-423

Warembourg M, Leroy D (2004) Comparative distribution of estrogen receptor $\alpha$ and $\beta$ immunoreactivities in the forebrain and the midbrain of the female guinea pig. Brain Res 1002:55-66. doi:10.1016/j.brainres.2003.12.014

Wood RI, Newman SW (1999) Androgen receptor immunoreactivity in the male and female Syrian hamster brain. J Neurobiol 39:359-370

Woodruff AR, Sah P (2007a) Inhibition and synchronization of basal amygdala principal neuron spiking by parvalbumin-positive interneurons. J Neurophysiol 98:2956-2961. doi:10.1152/jn. 00739.2007

Woodruff AR, Sah P (2007b) Networks of parvalbumin-positive interneurons in the basolateral amygdala. J Neurosci Off J Soc Neurosci 27:553-563. doi:10.1523/JNEUROSCI.3686-06.2007

Zhou J, Pfaff DW, Chen G (2005) Sex differences in estrogenic regulation of neuronal activity in neonatal cultures of ventromedial nucleus of the hypothalamus. Proc Natl Acad Sci USA 102:14907-14912. doi:10.1073/pnas.0507440102

Zimmermann L, Schwaller B (2002) Monoclonal antibodies recognizing epitopes of calretinins: dependence on $\mathrm{Ca}^{2+}$-binding status and differences in antigen accessibility in colon cancer cells. Cell Calcium 31:13-25. doi:10.1054/ceca.2001.0255 